New Models of Public Ownership in Energy

Aoife Brophy Haney and Michael G. Pollitt

September 2010

CWPE 1055 \& EPRG 1030 


\title{
New Models of Public Ownership in Energy
}

\author{
EPRG Working Paper 1030
}

Cambridge Working Paper in Economics 1055

\section{Aoife Brophy Haney and Michael G. Pollitt}

\begin{abstract}
This paper discusses some of the new and continuing ways in which the public sector is involved in the electricity / energy sector around the world. This involvement continues to be significant in spite of the longrunning trend towards privatisation, competition and independent regulation in the energy sector. We discuss why the theoretical case for public ownership might be more attractive now than in the recent past. We then discuss six case studies of modern public ownership drawn from the UK (Great Britain and Northern Ireland), Denmark, New Zealand, Finland and Chile. The investments covered include wind and nuclear power, LNG facilities, electricity and gas distribution investments and energy service companies for combined heat and power. We conclude with some outstanding questions raised by the apparently favourable conditions for increased public involvement in energy.
\end{abstract}

Keywords

JEL Classification public ownership, electricity, gas

L32, L94, L95
Contact

Publication

Financial Support m.pollitt@jbs.cam.ac.uk

September 2010

World Bank, TSEC 1 COUNCIL 


\title{
New Models of Public Ownership in Energy ${ }^{1}$
}

\author{
Aoife Brophy Haney \\ and \\ Michael G. Pollitt \\ ESRC Electricity Policy Research Group and Judge Business School \\ University of Cambridge
}

24 September 2010

\section{Background and current challenges facing the power sector}

This paper discusses some of the new and continuing ways in which the public sector is involved in the electricity / energy sector around the world. This involvement continues to be significant in spite of the long-running trend towards privatisation, competition and independent regulation in the energy sector (see Pollitt, 2008a, on the global trends). Indeed all of our examples are drawn from countries - the UK (Great Britain and Northern Ireland), Denmark, New Zealand, Finland and Chile - in which the trend towards liberalisation has been apparent and where the liberalised market and regulatory arrangements are often thought to be examples of good practice worthy of being studied and adopted in other countries.

The public involvement we discuss is occurring in different stages of the energy system, in projects with very different risk and technology characteristics. Thus we discuss examples of investments in electricity generation (nuclear and renewable), transmission and distribution (of both electricity and gas) and in LNG import facilities (where the power sector is an anchor customer).

It is important to say at the outset what we mean by public ownership. Traditionally public ownership tended to take one of two forms in energy: a large state owned company (SOE) (e.g. the Central Electricity Generating Board (CEGB) in Great Britain) or an often much smaller local municipally owned utility (e.g. a town level electricity distribution utility). Both of these types of entities tended to be $100 \%$ owned by the central government or the local authority. In some countries other hybrid ownership forms developed that could not be

\footnotetext{
1 This work has been supported by the World Bank, whose encouragement is acknowledged. We would particularly like to thank Maria Vagliasindi for her comments. All views expressed are the opinions of the authors and should not be taken to the views of the World Bank or any of its employees. The authors would like to acknowledge the ongoing support of the ESRC's TSEC project and the very helpful comments of one anonymous referee and Simon Taylor.
} 
characterised as either government ownership or private ownership (in the conventional tradable shareholder-owned firm sense). ${ }^{2}$ These included rural electric cooperatives in the US or customer owned utilities in Denmark. Nowadays, as we shall demonstrate, public involvement in ownership (in the sense of residual control rights, following Hart and Moore, 1990) takes many different forms. Many SOEs and municipal companies have been part privatised and special purpose vehicles (SPVs) for specific investments (including several of our case studies) can have multiple public sector and private sector shareholders. Special types of companies, such as community interest companies (see section 4.1), consumer trusts (see section 4.4) and companies limited by guarantee (see section 4.5), have important characteristics of publicly owned companies. These include public appointment of directors and restrictions on the tradability of ownership rights which make them operate very like many more typical government owned companies. The main difference is that equity risk is transferred to consumers. The benefits include safeguarding the interests of consumers but within a lighter touch regulatory regime; as well as the potential to raise capital for financing future investment relatively cheaply (Helm and Tindall 2009; Birchall 2002). In our case studies we take public ownership to be a broad term which encompasses all types of companies which essentially restrict ownership and control rights in ways broadly similar to traditional SOEs and municipally owned utilities. Public ownership thus encompasses both traditional forms of public ownership and new forms of public involvement.

This paper is motivated by five current challenges facing the wider energy sector, and the power sector in particular. These challenges set the scene for the analysis we set out in the next section and for the case studies. While we do not necessarily accept that these challenges are equally legitimate in all jurisdictions, they are perceived to be important by political decision makers in many jurisdictions and in each case they do cast doubt on the universal applicability of a wholly privately owned, competitive and independently regulated electricity supply industry.

First, even after 20 or more years of electricity market liberalisation, reform remains a work in progress. As noted in Pollitt (2009)'s review of progress with electricity liberalisation in the European Union (EU), it is difficult to find conclusive evidence of the consistently beneficial effects of the reforms actually implemented in many countries. There are examples of successful reform (e.g. UK, Nordic countries, Chile and Argentina) ${ }^{3}$ but there are notable reforms which have stalled (e.g. in many US states, including California, and in South Africa, Turkey and Ukraine) and many others of slow progress (e.g. in most continental European countries, China and Brazil) ${ }^{4}$. Public ownership

\footnotetext{
${ }^{2}$ See Pollitt (1995) for a general discussion of ownership forms in the global electricity supply industry.

${ }^{3}$ A survey of global lessons from electricity reform can be found in Mota et al. (2005). See for example: Newbery and Pollitt (1997) and Domah and Pollitt (2001) for the UK; Pollitt (2008b) for Argentina; Pollitt (2004) for Chile.

${ }^{4}$ For more mixed experiences see for example: Victor and Heller (2007) on China, Brazil and South Africa.
} 
remains a significant way in which governments can attempt to insure against and potentially prevent undesirable liberalisation outcomes.

Second, climate change and related policies impose significant new investment requirements on the power sector. Continuous technological improvements (combined with reasonably benign fossil fuel prices) ensured significant real unit cost reductions in power costs (and even larger reductions in the costs of energy services) between 1900 and 20005. However since then climate policy (with the objective of reducing carbon dioxide and equivalent Greenhouse gases) and sister policies aimed at promoting the percentage of electricity generated from renewable sources (and to reduce demand in high demand countries) have begun to significantly drive costs in many power sectors. While this has mainly affected OECD countries (particularly within Europe) it has implications for developing countries many of whom have adopted renewable polices (China has currently 24+ GW of wind capacity - the third highest in the world and growing very rapidly). Indirectly, such switching of emphasis in OECD countries is likely to have created mixed effects. On one hand, there have been learning benefits for other countries in renewables (and funding for projects, via the Clean Development Mechanism of the UN FCCC which allows for the creation of tradable carbon credits from investments in renewable projects in the developing world). On the other, there may have been detriments caused by the slowing of technical progress and investment in conventional generation technologies. The policy targets at the individual country level are ambitious and create significant investment requirements for the power sector (perhaps doubling or trebling the sector's investment requirements above a no-policy baseline). Such investments in low carbon (e.g. nuclear) and renewable generation expose investors to substantial government policy change risks, especially given that the payback periods for many of these investments are long (15-30 years). Public ownership may be a way to ensure that the large scale investment requirements of the power sector are met. Indeed the initial history of public ownership of the power sector in many countries was driven by the perceived inability of the private market to finance the large investment requirements of the sector during the electrification period (Millward, 2010).

Third, there has been a re-emergence of political concerns about fossil fuel energy security in many countries. The EU is a good example of this. Here the Ukrainian gas supply crises of 2006 and 2009 resulted in reduced supplies of Russian gas into the European Union. This was due to a dispute between Ukraine and Russia, which saw the reduction of supplies to the gas transit country Ukraine leading to reduced onward flows of Russian gas to the large EU gas market. This has heightened concerns about gas security in the EU and reduced the willingness of politicians to allow increases in the dependence of the power sector on combined cycle gas turbine (CCGT) power plants (see Noel, 2009). In the UK, for instance, the energy regulator, conducted a significant review project into UK energy security (Project Discovery), which examined the need to

\footnotetext{
${ }^{5}$ See Fouquet and Pearson (2006) for the long term trend in the cost of lighting as an example of the long trend reduction in the cost of energy services.
} 
encourage more LNG terminals, gas storage facilities and alternative sources of power and heat (see Ofgem, 2010). More generally there remain concerns about 'peak oil' and 'peak gas' - the idea that the global output of oil and gas cannot continue to increase in line with growing demand (driven by Chinese and Indian industrialisation) without substantial price rises (the factual basis for which is well discussed in Mills, 2008). Politically motivated energy security investments are by their nature dependent on interference in the normal operation of the global energy market (which does handle external political risks quite well in most circumstances), this may give rise to public ownership of strategic national energy security assets (such as LNG import facilities in small countries).

Fourth, the move towards large scale privatisation with independent regulation may raise issues of political legitimacy. Privately owned assets regulated by an arms-length government regulator may make it difficult for the government to address social concerns around energy markets. A good example of this might be the issue of energy poverty and tariffs for vulnerable customers ${ }^{6}$. Private ownership may be more efficient in terms of production costs but may not be particularly able to meet democratic concerns about desirable crosssubsidies between and within customer groups. Thus public ownership may have a significant role to play in providing energy services to certain customers on a non-economic price basis. It is technically possible to subsidise energy bills directly and retain private ownership but public ownership might be a way to do this in the absence of an adequate tax and benefit system, or where the transaction costs of raising taxes and distributing benefits are significant both for the government and for the individual (in terms of filling in subsidy claim forms). Public companies can also be seen to have more accountable governance processes (e.g. for the selection of directors) and be closer to their customers, if they are small. While small private energy companies may incur disproportionately high transactions costs (in terms of administrative costs per customer), smaller public companies may benefit from low transactions and production costs (e.g. the willingness of local directors to forgo fees (see section 4.1), or ex-employees to work part-time for nothing).

Fifth, the global financial crisis has raised particular concerns in the energy sector that the private capital markets may not be able to fund the rising investment requirements of the sector. This point is related to the second challenge and may be especially likely to be true of investments which rely on politically vulnerable government support mechanisms. Of course, this is in the context of the need for fiscal restraint and the currently reduced capability of the public sector to raise taxes and finance debt. In such circumstances there may be a case for increased government participation in energy investment projects in order to encourage or replace private sector investment. This may be of particular interest if international energy companies reduce their equity and debt investments in small developing countries and host country governments are forced to step in to ensure that large strategic investments (e.g. in nuclear or in LNG facilities) happen or indeed there is more local funding of smaller scale

\footnotetext{
${ }^{6}$ Energy poverty may be defined as occurring when a household spends more than a certain percentage of its annual income on domestic energy for power and heat/cooling. In the UK this percentage is defined to be $10 \%$.
} 
energy projects (such as small wind parks). It is also possible that rapidly growing countries such as China or the Gulf States would be in relatively advantageous fiscal position at a time when private firms relying on international capital markets were less able to invest in projects (as for example is the case for nuclear investment in Abu Dhabi).

In what follows we discuss theories of public ownership in Section 2 and their relevance to the energy sector and the current challenges facing the energy sector. Section 3 discusses the general background to the six case studies. Section 4 presents the six case studies of continuing public ownership - Middelgunden wind park, Denmark; Olkiluoto 3 nuclear plant, Finland; LNG terminals, Chile; electricity distribution companies, New Zealand; electricity and gas transmission interconnectors, Northern Ireland; and combined heat and power (CHP) based energy service companies, Great Britain. Section 5 concludes.

\section{Theories of public ownership and their application to energy}

We outline four frameworks which examine the role of public vs private ownership in regulated sectors, such as energy. These frameworks are grounded in the early literature on public choice and the theory of economic regulation. For each, we introduce the theoretical results, what they depend on and then ask whether the current challenges facing the power industry are likely to imply stronger support for public ownership.

We begin with looking at Laffont and Tirole (1993) who examine the incentive properties of public versus private ownership. Laffont and Tirole suggest public ownership has potentially significant costs associated with: the absence of capital market monitoring; soft budget constraints in the public sector; the expropriation of investments within the public sector; the lack of precise objectives; and its vulnerability to lobbying by interest groups. These costs may be offset by potential benefits arising from the ability to target social welfare at the expense of profit maximisation. In addition, public ownership has the potential to provide a better solution to the principal-agent problem within the firm which may be problematic in large private sector companies. They suggest that private firm principal-agent problems may be further exacerbated by the fact that private firms in regulated markets have conflicting principals shareholders and regulators. Thus private firms may be vulnerable to appropriation of investments by managers, while public sector managers may be forced to behave inefficiently as a result of poorly defined and difficult to measure social goals. Overall, this suggests ambiguous results for the relative attractiveness of public vs private firms in heavily regulated industries. To get a handle on the net balance of the different incentives, there is a need to examine detailed empirical evidence on performance.

We can think about the current challenges facing the energy sector, outlined in section 1, and how they relate to the key elements of theory. In terms of the costs of public ownership it would seem to be the case that the current fiscal crisis and financial crisis might significantly reduce the costs of public ownership. This is 
because the capital market has shown itself to be a poorer monitor of investments than previously thought, while fiscal retrenchment increases the likelihood that public sector entities will face harder budget constraints, less appropriation of investments than the private sector (where the risk of appropriation has risen), more precise objectives, while being less vulnerable to obviously costly lobbying. The benefits of public ownership remain largely the same as before (though there may be more temptation to privatise existing assets to raise revenue). In terms of the principal-agent problems faced by public and private firms: the financial crisis and the rising investment requirements exacerbate the problem of multiple principals as the regulator becomes more demanding, while public sector firms in theory benefit from being better able to meet clearer social goals (driven by quantitative targets for renewable penetration and for carbon and demand reduction). The case for some public ownership therefore looks stronger on incentive grounds (albeit relative to a low base in many countries).

Hart et al. (1997) look at the incentives in public-private partnerships with a view to asking why services cannot be contracted out to the private sector. Essentially this approach focuses on why the public sector cannot simply contract for public goods or services for poor consumers. Indeed this would seem to be a key issue in the power sector - clearly it is possible to contract for renewables, carbon reducing investments such as nuclear, demand reduction, energy security investments etc. In many jurisdictions this is precisely what is happening. Hart et al. conclude that there are only a narrow range of circumstances where public ownership of the service providing assets would be preferable to contracting out to the private sector. These are: where the risk of non-contractible quality loss is serious; competition for the supply of the service is weak (i.e. there are a lack of bidders, particularly in successive contracting rounds); consumer choice is ineffective in punishing underperformance on the contract; and where the bidding firms don't care about the reputation loss of under-performance.

Applying this approach to the current challenges facing the energy sector, the key issues include the ability to run competitive auctions for the supply of publicly procured goods (though they are often paid for by levies on energy consumers) and the ability to punish contractual underperformance. Clearly in some countries there are issues about how many energy companies could credibly bid in government investment competitions and indeed maintaining some part-publicly owned companies may be a way of preventing unhelpful consolidation of the industry. More use of auctions might create private incentives to consolidate the industry and hence lead to a natural re-emergence of monopoly companies. Similarly many large investment projects - such as nuclear power plants and LNG facilities may be one-offs - particularly in small countries - delivered by special purpose vehicles. In these cases consumer choice and reputation effects may be limited and some direct government participation may be justified because of the vulnerability of leveraged investment vehicles to 
bankruptcy. ${ }^{7}$ This suggests that smarter procurement from the private sector will be necessary to maintain the strength of the case for $100 \%$ private ownership of publicly procured goods such as low carbon investments.

Gilbert and Newbery (1994) focus on the incentives on regulators to appropriate private firm investments. They have in mind a price-setting utility regulator facing a privately owned monopoly service provider. The private monopolist first has to decide on the level of investment and the regulator then decides on the regulated price for the services. In a repeated game there may be multiple investments a different dates and repeated price resets. Gilbert and Newbery show that the private monopolist will invest when:

$$
(1-P)(c-b)>r
$$

Where $\mathrm{P}=$ the probability of a low demand state $(\mathrm{D}=1-\mathrm{s}$, rather than high demand $\mathrm{D}=1$ ); $\mathrm{c}$ is the marginal cost of the alternative company (i.e. the nationalised monopolist); $\mathrm{b}$ is the private monopoly's marginal cost; $\mathrm{r}=$ cost of capital + depreciation. This implies private investment is more likely when demand expected to be high, the cost advantage of the monopolist is higher and when the cost of capital is lower. This is because appropriation is less likely because the nationalisation involves higher operating and capacity reduction costs for the regulator, and investment payback is faster.

They also show that the regulator will appropriate the investment by setting low regulated prices and running the risk of the private monopolist exiting (via bankruptcy) when:

$$
(1-\theta) r>\frac{(c-b)(1-\sigma P)-r}{i}
$$

Where $\theta=$ social weight on profits; $\mathrm{i}=$ discount rate of regulator.

This implies that the higher the discount rate, the lower the social weight on profits and the higher the probability of low demand the more likely the regulator is to appropriate via setting low regulated prices and driving the private monopolist towards bankruptcy or reducing its long term incentives to invest.

Applying this in the current context, we might suggest that current financial and fiscal crisis reduces the social weight on profits (and the political and regulatory desire to support profitable private firms) and leads to a higher social discount rate (as quick fixes become more attractive). Idiosyncratic private investments with strong government involvement via the planning process are at less of a cost advantage in construction and given their low operating costs relative to capital cost impose lower increases in running costs if nationalised since their cost structure is locked in at construction (particularly for wind parks and nuclear power plants). There is low actual demand growth and hence a capital strike by the private sector is less of a threat to the government (in terms of leading to capacity shortages) than it might have been. Taken together this does

\footnotetext{
7 Though if these investments are undertaken by global multinationals seeking business in other countries, this effect may not be as significant as it might appear.
} 
seem to suggest that appropriation by regulators of private sector investments is more likely in the light the current challenges. ${ }^{8}$

Finally, we turn to risk allocation issues. A helpful synthesis of the literature on efficient risk allocation between the public and private sectors is contained in the World Bank's Risk Allocation and Sharing Tool Kit ${ }^{9}$. This suggests that the following risks are best handled by the private sector: economic and financing risks; construction risks; operational risks; and commercial risks. The risks most efficiently handled by the public sector are political and legal risks.

The issue with the current challenges is whether the optimal risk allocation is changing. The economic and financing risk advantages of the private sector are diminished in a financial crisis, if capital is restricted by private banks need to rebuild their balance sheets. Construction risks for large first-of-a-kind investments are significant, while the benefits in terms of learning accrue to others (followers). This increases the case for the public sector shouldering a part of first of a kind construction risks (e.g. for nuclear power plants). ${ }^{10}$ Commercial risks in terms of the ability to sell the electricity, gas or carbon reduction may be increased if there is a threat to the continuation of liberalised energy and emissions markets (as there would appear to be in the EU - see Pollitt, 2009, and Ofgem, 2010). A general increase in the political and legal risks facing the sector, as it struggles to meet the government targets imposed on it, would also argue for increased public ownership. Thus overall it would seem to be the case that the context and nature of risks favour increasing public sector involvement via public ownership or the shifting of financial liability on to the public sector (which itself may improve the case for public ownership). ${ }^{11}$

Taken together all four of the theoretical approaches we examine do seem to suggest that the current challenges facing the power sector do improve the case for some form of public involvement in the industry.

\section{Introduction to our six public involvement cases}

A key starting point for the discussion of actual cases is the observation that public ownership has never gone away in the energy sector. Even in the EU where there has been significant and co-ordinated market liberalisation - public ownership has never been challenged as part of the liberalisation process and privatisation remains patchy and incomplete in many countries, as shown in Figure 1 below:

\footnotetext{
8 This is not to say that there are not significant appropriation risks within the public sector. Public ownership itself may be a vehicle for the appropriation of taxpayer and customer wealth by public sector employees and managers, politicians and civil servants (see for example Shleifer and Vishny, 1994).

${ }^{9}$ See www.worldbank.org

10 This relates to the fact that such projects might be 'too big to fail', with an implied guarantee from the state to underwrite the completion of the project should the private sector fail.

11 It is important to point out that shifting risk onto the public sector is not necessarily a good thing. The public sector may be exposing itself to significant risks that it poorly understands (in contrast to the situation when these risks are left with the private sector). It may also attempt to manage such risks by incurring the significant transaction costs associated with very tight and detailed regulation which may impose large costs of its own.
} 
Figure 1: Electricity Sector ownership in selected EU countries

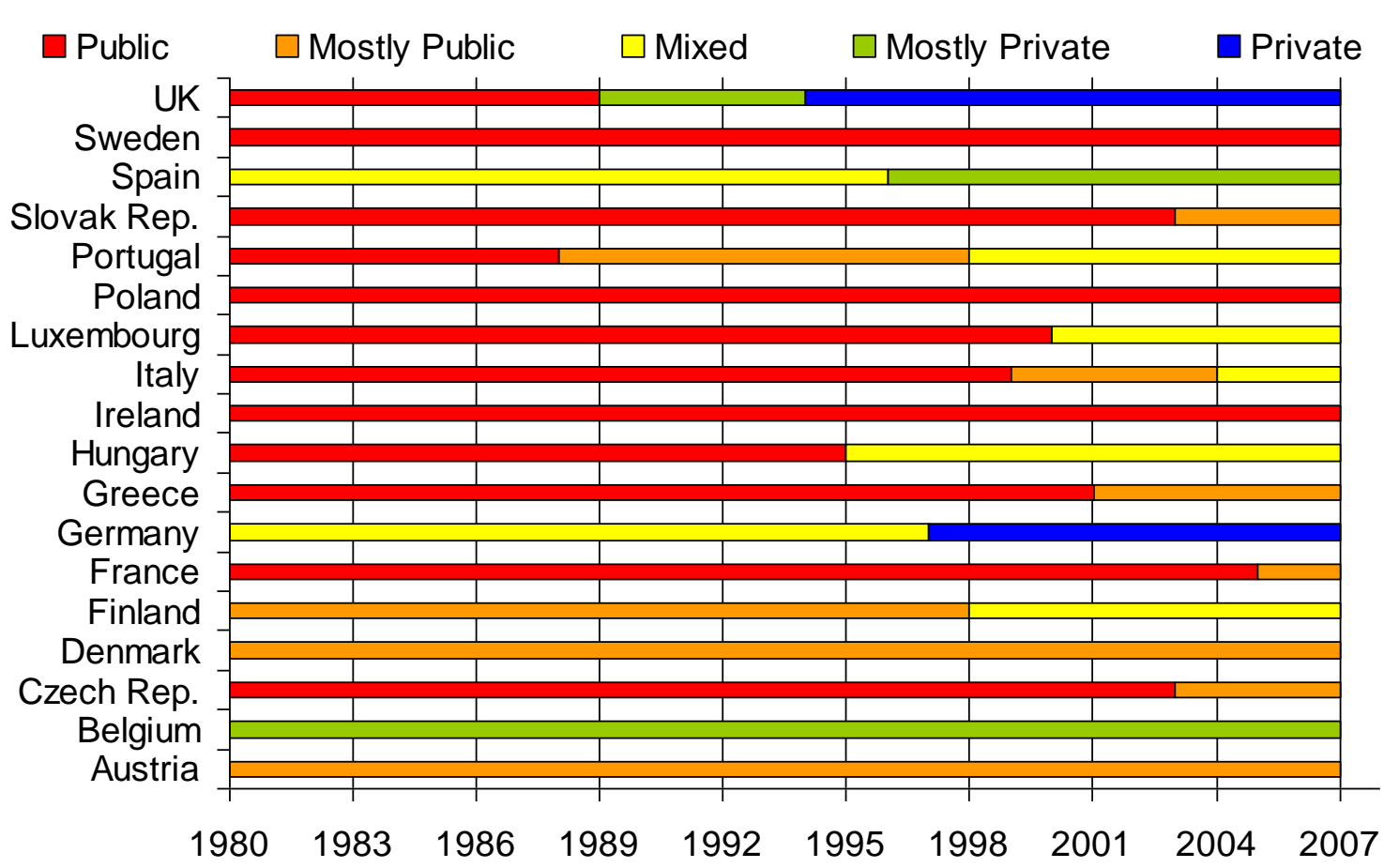

Source: OECD international regulation database, 2009

Indeed what is striking is that, looking internationally, many of the jurisdictions with the most significant liberalisation in terms of the opening up to competition of both wholesale and retail electricity markets retain significant public ownership ${ }^{12}$. Littlechild (2006) identified the UK, Victoria, New South Wales, Norway, Sweden, New Zealand, Texas and Ohio as leading the world in terms of retail market opening (in addition to having competitive wholesale markets). Several of these leaders have significant continuing public ownership, for example New Zealand, New South Wales, Norway and Sweden. Apart from the UK, there has been only limited movement towards full privatisation (where private ownership was not initially dominant) and all retain some public or cooperative ownership in energy.

Therefore it is important to acknowledge that liberalised electricity markets seem to be able to accommodate some degree of continuing public ownership (albeit naturally reduced somewhat by the free entry of private firms). Equally, we should point out that the type of public ownership that continues in these jurisdictions is not the classic SOE or monopoly municipally owned utility. Indeed, while privatisation is not a requirement of liberalisation, some vertical and horizontal unbundling of SOEs is a requirement of typical liberalisation programmes. This often, at least initially, creates more and / or smaller public companies (e.g. Turkey, China, New Zealand).

The picture that our case studies suggest is one where continuing public involvement in energy is much more varied than before and involves a large variety of different capital structures and governance arrangements. It also 12 Though the table understates the influence of cross border competition within Europe which
does reduce the influence of domestic state owned enterprises. 
reveals that public entities remain involved in all of the significant investment types in the power system.

Thus we chose six types of cases, where the current challenges can be clearly seen to be in operation. The first (section 4.1) is an offshore wind farm in Denmark and is a classic climate policy inspired investment, also motivated by a desire for domestic energy security, displaying significant local accountability and a range of sources of finance. The second (section 4.2) is a first-of-a-kind nuclear power plant in Finland. This is also climate policy and domestic energy security policy inspired and very risky for the private sector. The third (section 4.3 ) is a pair of LNG re-gasification (import) plants in Chile. These are large energy security inspired investments. They are difficult to finance in the context of a moderately sized developing country that might find attracting foreign capital for a large project difficult. ${ }^{13}$ The fifth (section 4.4) examines local electricity distribution in New Zealand. Here we see a range of different types of public ownership co-existing within a competitive national wholesale and retail power market. These companies face the full range of current energy challenges with a particular emphasis on the need for local accountability. The fourth (section 4.5) is a group of three transmission infrastructure investments in Northern Ireland. These are classic price regulated sunk investments subject to significant appropriation risks and requiring local accountability in their use. The sixth (section 4.6) looks at models of combined heat and power (CHP) based energy service companies (ESCOs) in Great Britain. The impetus to set up these companies is the desire to reduce local council energy costs and to meet social objectives in providing cheap power and heat to poor tenants in council housing, hence requiring strong local accountability. They are further motivated by local climate change policy objectives, themselves inspired by national and international targets. Interestingly these ESCOs display a range of ownership forms. The linkages between the six cases studies are reviewed in section 4.7.

13 Though Chile has a very low country risk premium for a developing country. See http://www.sjsu.edu/faculty/watkins/countryrisk.htm (Accessed 24 September 2010). 


\section{Case studies in modern public ownership}

Table 1: Summary of ownership structures involved in the case studies

\begin{tabular}{|c|c|c|c|}
\hline Case study & Industry & Ownership & Share \\
\hline 1. Denmark - & Electricity & Consumer cooperative & $50 \%$ \\
\hline Middelgrunden offshore & generation & State ownership & $37 \%$ \\
\hline wind farm & & $\begin{array}{l}\text { Consumer-owned energy } \\
\text { companies }\end{array}$ & $13 \%$ \\
\hline 2. Finland - Olkiluoto & Electricity & Large industrial consumers & $57 \%$ \\
\hline nuclear power plant & generation & $\begin{array}{l}\text { Utilities with part municipal } \\
\text { ownership }\end{array}$ & $43 \%$ \\
\hline 3. (a) Chile - Quintero & Gas production & Private & $80 \%$ \\
\hline LNG terminal & & State ownership & $20 \%$ \\
\hline 3. (b) Chile - Mejillones & Gas production & Private & $50 \%$ \\
\hline LNG terminal & & State ownership & $50 \%$ \\
\hline 4. (a) New Zealand - & Electricity & Consumer trust & $75.1 \%$ \\
\hline Vector & distribution & Private & $24.9 \%$ \\
\hline $\begin{array}{l}\text { 4. (b) New Zealand - } \\
\text { Orion }\end{array}$ & $\begin{array}{l}\text { Electricity } \\
\text { distribution }\end{array}$ & Local authorities & $100 \%$ \\
\hline $\begin{array}{l}\text { 4. (c) New Zealand - } \\
\text { Eastland Network }\end{array}$ & $\begin{array}{l}\text { Electricity } \\
\text { distribution }\end{array}$ & Community trust & $100 \%$ \\
\hline $\begin{array}{l}\text { 5. Northern Ireland - } \\
\text { Moyle interconnector }\end{array}$ & $\begin{array}{l}\text { Electricity } \\
\text { transmission }\end{array}$ & $\begin{array}{l}\text { Member-owned - mutual } \\
\text { ownership model }\end{array}$ & $100 \%$ \\
\hline $\begin{array}{l}\text { 6. (a) Great Britain - } \\
\text { Aberdeen ESCO }\end{array}$ & $\begin{array}{l}\text { Electricity/heat } \\
\text { generation and } \\
\text { retail }\end{array}$ & $\begin{array}{l}\text { Local council - not-for-profit } \\
\text { status }\end{array}$ & $100 \%$ \\
\hline $\begin{array}{l}\text { 6. (b) Great Britain - } \\
\text { Sheffield ESCO }\end{array}$ & $\begin{array}{l}\text { Electricity/heat } \\
\text { generation and } \\
\text { retail }\end{array}$ & Private finance initiative & $\begin{array}{l}100 \% \\
\text { (35-year } \\
\text { contract) }\end{array}$ \\
\hline
\end{tabular}

\subsection{Wind power in Denmark}

In 2008, Denmark had an installed wind capacity of 3157 MW (Danish Energy Agency). In absolute terms, a number of other European countries are ahead. Germany, for example, has the largest installed capacity with over 23,000 MW in 2008, followed by Spain with almost 17,000 MW14. What makes the Danish case unique is that wind capacity now makes up almost $20 \%$ of the country's total electricity production, as can be seen from Figure 2 .

Achieving this high share of wind in the energy mix has not happened overnight. Danish energy policy has been supportive of renewable energy development since the 1980s. There has also been a bottom-up push for wind through an organized grass-roots movement (Lipp, 2007). During the 1970s, the first wave of modern wind turbine development came from private individuals without any

\footnotetext{
14 See EWEA (undated).
} 
government support. Since then, the Danish government has encouraged local private ownership of wind turbines.

Table 2: Denmark at a glance

\begin{tabular}{ll}
\hline Total electricity generation & $36,413 \mathrm{GWh}$ \\
2008 & \\
Total gas demand 2008 & $190,888 \mathrm{~T}$ J \\
GDP per capita 2008 (\$ PPP & $\$ 34,004$ \\
constant 2005) & \\
GDP growth 2007 & $1.65 \%$ \\
GDP growth 2008 & $-1.14 \%$ \\
Electricity price for & $\$ 0.396 / \mathrm{kWh}$ \\
households 2008 (including & \\
tax) & \\
Population 2008 & $5,493,621$ \\
\hline
\end{tabular}

Source: World Bank - World Development Indicators; IEA - Electricity information; EIA - Electricity prices for households

Figure 2: Denmark electricity mix 2008

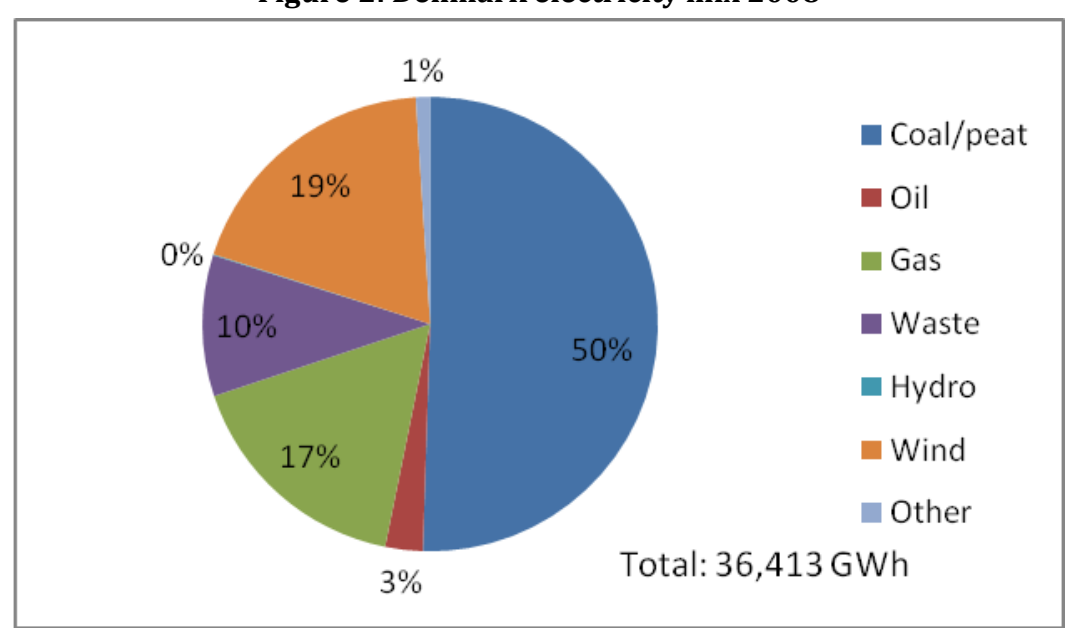

Source: IEA - OECD Electricity and Heat Generation

A feed-in tariff was introduced in 1993. Since then, it has been central to the diffusion of wind energy in the country. The tariff obliged utilities to pay $85 \%$ of the price paid by consumers for wind-generated electricity. This represented a generous subsidy to wind because total taxes on household electricity use in Denmark are over $50 \%$ of final prices (IEA, 2009a, p. 112) There have been a number of complementary policies including subsidies (30\% of investment) and tax exemptions (up to 7,000 $\mathrm{kWh}$ tax-free electricity generation) for private wind turbine owners (Lipp, 2007). The tax refund amounted to 0.27 DKK per kWh (3.7 eurocents per kWh) (Meyer, 2007). In 1999, Denmark decided to replace the feed-in tariff with a system based on a renewable portfolio standard and tradable green certificates. The feed-in tariff was removed gradually from 2001 (Bolinger, 2001). Wind generators are now paid the wholesale market price plus an environmental premium of approximately $0.013 € / \mathrm{kWh}$ (Lipp, 2007). 


\begin{tabular}{lllll}
\hline & $\begin{array}{l}\text { Utilities/corporate } \\
\text { owners (\%) }\end{array}$ & Farmers (\%) & $\begin{array}{l}\text { Cooperatives } \\
(\%)\end{array}$ & $\begin{array}{l}\text { Total 2009 } \\
\text { wind } \\
\text { capacity } \\
\text { (MW) }\end{array}$ \\
UK & 98 & & & 4,051 \\
Germany & 55 & 1 & 0.5 & 25,777 \\
Spain & $99+$ & 35 & 10 & 19,149 \\
Denmark & 12 & $<0.5$ & 0 & 3,465 \\
\hline
\end{tabular}

Source: Pollitt (2010); The Wind Power

As shown in Table 3, wind ownership in Denmark has been largely communitybased in contrast to other European countries. This started out as a bottom-up push from communities and was later encouraged by government policy throughout the 1980s and 1990s. Middelgrunden offshore wind farm is an example of a hybrid form of ownership that started out as a partnership between a local municipal utility, Copenhagen Energy, and a local cooperative.

\section{Middelgrunden offshore wind farm}

Middelgrunden wind farm was built in 2000. It has a total of 20 wind turbines with a capacity of $2 \mathrm{MW}$ each, supplying approximately $4 \%$ of total power for the city of Copenhagen (with a total population of approximately 530,000). Total investment costs for the project came to $€ 44.9$ million, $€ 26.1$ million of which were for the wind turbines. Copenhagen Energy and the Middelgrunden cooperative each own 10 wind turbines in the farm (Sorensen et al., 2002).

The Middelgrunden Wind Turbine Cooperative was established in 1997 as a private partnership under Danish law, i.e. a partnership between consumers who have direct ownership of the turbines. It was the first community-owned offshore wind project and also the largest community-owned wind project at the time (Bolinger, 2001). The cooperative had a total of 8,650 members at the outset with 40,500 shares (in total). Each share represents production of 1,000 $\mathrm{kWh} /$ year and was sold for 4,250 DKK (€567). An average shareholder would have invested a total of $€ 2655$. Over a 20 -year period, the typical rate of return after depreciation would be $7.5 \%$ (Larsen et al., 2005). The transition away from the feed-in tariff may have an impact on the rate of return due to uncertainty over output sales. Some see this uncertainty as a barrier to further cooperativebased wind development in Denmark. The worst-case scenario for Middelgrunden is a rate of return of $4.44 \%$ if output cannot be sold once the feed-in tariff comes to an end (Bolinger, 2001).

Five partners of the cooperative are elected to a management committee as well as two substitutes by the partnership assembly, where each partner has one vote. Management partners are elected for a term of 2 years. Not more than one management partner can be from the same household. The management 
committee as a whole or members of the committee can be dismissed by simple majority at the partnership assembly ${ }^{15}$.

Table 4: Middelgrunden wind turbine ownership

\begin{tabular}{llll}
\hline $\begin{array}{l}\text { Organisation } \\
\text { Middelgrunden Wind }\end{array}$ & Share & Ownership & Financing \\
Turbine Cooperative & & $\begin{array}{l}\text { Private partnership; } \\
\text { 8,650 members with a } \\
\text { total of 40,500 shares }\end{array}$ & $\begin{array}{l}\text { Entirely equity- } \\
\text { based through } \\
\text { members }\end{array}$ \\
& & $74 \%$ state-owned & $57 \%$ equity and \\
Dong Energy & $50 \%$ & utility & 10.88\% debt-financed \\
& & Holding 6.95\% Syd \\
& & Energy Net (both \\
& & \\
& & \\
& &
\end{tabular}

The remaining $50 \%$ of the project is now owned by Dong Energy which was founded in 2006 after the merger of six Danish energy companies, including Copenhagen Energy. The Danish state is the principal shareholder with $74 \%$ ownership as of the beginning of 2010. Among the minority shareholders are two of the largest consumer-owned energy companies in the country. SEAS-NVE Holding has a $10.88 \%$ share and is Denmark's largest energy cooperative. Syd Energi Net has a $6.95 \%$ share and is Denmark's third largest energy company. Dong Energy as a whole is $57 \%$ equity and $43 \%$ debt-financed. The debt is predominantly fixed-rate with a high degree of certainty. In 2009, the company issued bonds in the Euro market totally $€ 2$ billion and secured loans of $€ 250$ million from the European Investment Bank (Dong Energy, 2009).

Middelgrunden wind farm illustrates how a number of different forms of public ownership can coexist and complement each other. The local community is involved directly through the wind farm cooperative. At the same time, the wider Danish community is involved indirectly through large consumer-owned energy companies. Finally, the state retains a central position as majority shareholder in Dong Energy.

15 Source: Middelgrunden Wind Cooperative website. 


\subsection{Nuclear power in Finland: Olkiluoto nuclear power plant}

\begin{tabular}{|c|c|}
\hline $\begin{array}{l}\text { Total electricity generation } \\
2008\end{array}$ & $77,145 \mathrm{GWh}$ \\
\hline Total gas demand 2008 & $179,080 \mathrm{TJ}$ \\
\hline $\begin{array}{l}\text { GDP per capita } 2008 \text { (\$ PPP } \\
\text { constant 2005) }\end{array}$ & $\$ 33,377$ \\
\hline GDP growth 2007 & $4.2 \%$ \\
\hline GDP growth 2008 & $0.92 \%$ \\
\hline $\begin{array}{l}\text { Electricity price for } \\
\text { households } 2008 \text { (including } \\
\text { tax) }\end{array}$ & $\$ 0.172 / \mathrm{kWh}$ \\
\hline Population 2008 & $5,313,399$ \\
\hline
\end{tabular}

Source: World Bank - World Development Indicators; IEA - Electricity information; EIA - Electricity prices for households

There are currently four operating nuclear power reactors in Finland, in two different power plants. A fifth is under construction at Olkiluoto power plant and is due to be completed in 2012. The government in April 2010 approved plans for a further two units to be constructed after 2012. The nuclear share of total electricity production was $30 \%$ in 2007, as can be seen from Figure 3.

Olkiluoto power plant is located on Olkiluoto island in western Finland. The plant has two operating nuclear reactors with installed capacity of $860 \mathrm{MW}$ each. A third reactor is under construction with a net output of approximately 1,600 MW and a fourth is being planned. At present, the plant accounts for $64 \%$ of total nuclear installed capacity in Finland and this figure will increase when the third reactor becomes operational. Support for nuclear power in Finland has been relatively stable in the last few decades. A 2006 survey conducted by the nuclear industry shows that $50 \%$ are in favour and $20 \%$ are against nuclear power. Public acceptance of further nuclear developments - beyond those already planned - is, however, not so clear (IEA, 2007).

Olkiluoto 3 , the third reactor under construction, is the first new nuclear build in a liberalized market (IEA, 2009a). The total cost of the project is approximately $€ 3$ billion. The financing structure is innovative and builds on the structure for the previous reactors. The three reactors are owned and operated by Teollisuuden Voima Oy (TVO). TVO was founded in 1969 by 16 Finnish industrial and power companies to produce electricity for shareholders at cost price. The first reactor was connected to the grid in 1978 and the second in 1980. The organization as a whole is $43 \%$ owned by local utilities and $57 \%$ by large industrial consumers. Pohjolan Voima OJ (PVO) and Fortum Power and Heat are the largest shareholders. The majority of PVO's shares are owned by companies in the Finnish pulp and paper industry. Municipalities and utilities owned by municipalities make up the remainder of the shareholders. Fortum is a stock market listed utility in which the state has a 51\% stake (TVO, 2009). 


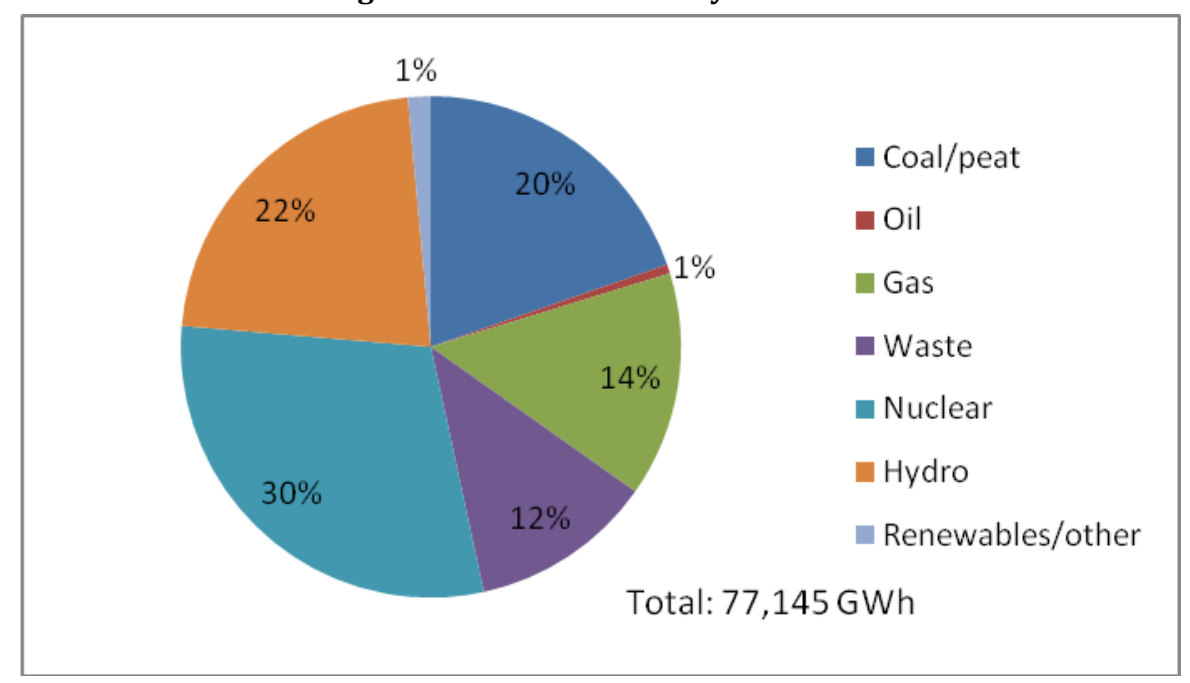

Source: IEA - OECD Electricity and Heat Generation

The board of TVO can have a minimum of 7 and a maximum of 10 members. Shareholders who own more than $20 \%$ and less than $50 \%$ have the right to appoint 3 members to the board. Elections take place annually at the shareholders' meeting.

Table 6: Olkiluoto 3 shareholders

\begin{tabular}{|c|c|c|}
\hline Organisation & Share & Ownership \\
\hline PVO & $60.2 \%$ & $\begin{array}{l}\text { Several companies in the } \\
\text { pulp and paper industry; } \\
\text { municipalities; } \\
\text { municipally owned } \\
\text { utilities }\end{array}$ \\
\hline Fortum & $25 \%$ & $\begin{array}{l}51 \% \text { state-owned stock- } \\
\text { market-listed utility }\end{array}$ \\
\hline Oy Mankala AB & $8.1 \%$ & $\begin{array}{l}\text { Subsidiary of a utility } \\
\text { owned by the city of } \\
\text { Helsinki }\end{array}$ \\
\hline EPV & $6.6 \%$ & $\begin{array}{l}\text { Regional energy } \\
\text { procurement company } \\
\text { owned by } 21 \text { local } \\
\text { utilities, mainly } \\
\text { municipally owned }\end{array}$ \\
\hline
\end{tabular}

Source: IEA (2007)

TVO has released 3 series of shares: the first is for electricity produced by current nuclear units; the second for electricity produced by Olkiluoto 3; and the third for TVO's share of electricity produced by the Finnish Meri-Pori coal plant. A majority of the Olkiluoto 3 shares are privately owned, however there is also considerable state and municipal ownership. Table 6 summarises the shareholders involved and their ownership structures (IEA, 2007).

Olikiluoto 3 is $75 \%$ debt-financed. The remaining $25 \%$ is provided by subordinated debt and equity from the shareholders. The project is financed on 
TVO's balance sheet, which means that recourse on loans is tied to TVO as a company and not just to the Olikiluoto 3 project itself. The long-term contracts to provide shareholders with electricity at production cost essentially transfer the project risks to the shareholders. This allows for a higher level of low-cost debt financing. This model of financing is particularly appropriate in the Finnish nuclear context given the high capital costs and high levels of industrial electricity demand. It also allows for risks to be shared across different types of actors, i.e. public, private and municipal (IEA, 2007).

The project itself has had significant construction cost problems. The reactor technology - third generation nuclear plant using the European Pressurised water Reactor (EPR) design - is new and very advanced. Construction cost risk lies with the consortium of Areva and Siemens that is delivering the reactor as a turnkey project (IEA, 2007). Costs are currently estimated to be around 50\% over budget and the project was originally due to be delivered in 2009 but is now not expected to start commercial operation until 2012 (Kanter, 2009).

\subsection{LNG in Chile}

Table 7: Chile at a glance

\begin{tabular}{ll}
\hline Total electricity generation & $58,509 \mathrm{GWh}$ \\
2007 & \\
Total gas demand 2008 & $84,028 \mathrm{TJ}$ \\
(2007) & $(155,995 \mathrm{TJ})$ \\
GDP per capita 2008 (PPP & $\$ 13,333$ \\
constant 2005) & $4.68 \%$ \\
GDP growth 2007 & $3.16 \%$ \\
GDP growth 2008 & $\$ 0.195 / \mathrm{kWh}$ \\
Electricity price for & \\
households 2008 (including & \\
tax) & $16,803,952$ \\
Population 2008 & \\
\hline \multicolumn{2}{c}{ Bank - World Development Indicators; IEA - Electricity information; } \\
\end{tabular}

The role of the state in LNG terminal ownership in Chile is driven above all by the need to diversify the Chilean energy mix. Chile does not have any significant local gas resources. Imports of gas from Argentina commenced in 1997, mainly for use in thermal power generation and for the industrial sector. Argentina has had difficulty meeting its own gas supply needs, however, and since 2005 exports to Chile have been falling. Supply cuts from Argentina started in 2004. In 2007, cuts reached up to $95 \%$ of committed volumes (Barroso et al., 2008). This has had a significant impact on the share of gas in electricity generation in Chile. In 2007, the share of gas in total electricity production was 8\%. As can be seen from Figure 5, this comes at the end of a phase of expansion starting at the end of the 1990s and subsequent decline from 2004 onwards (IEA, 2009b). 
Figure 4: Chile electricity mix 2007

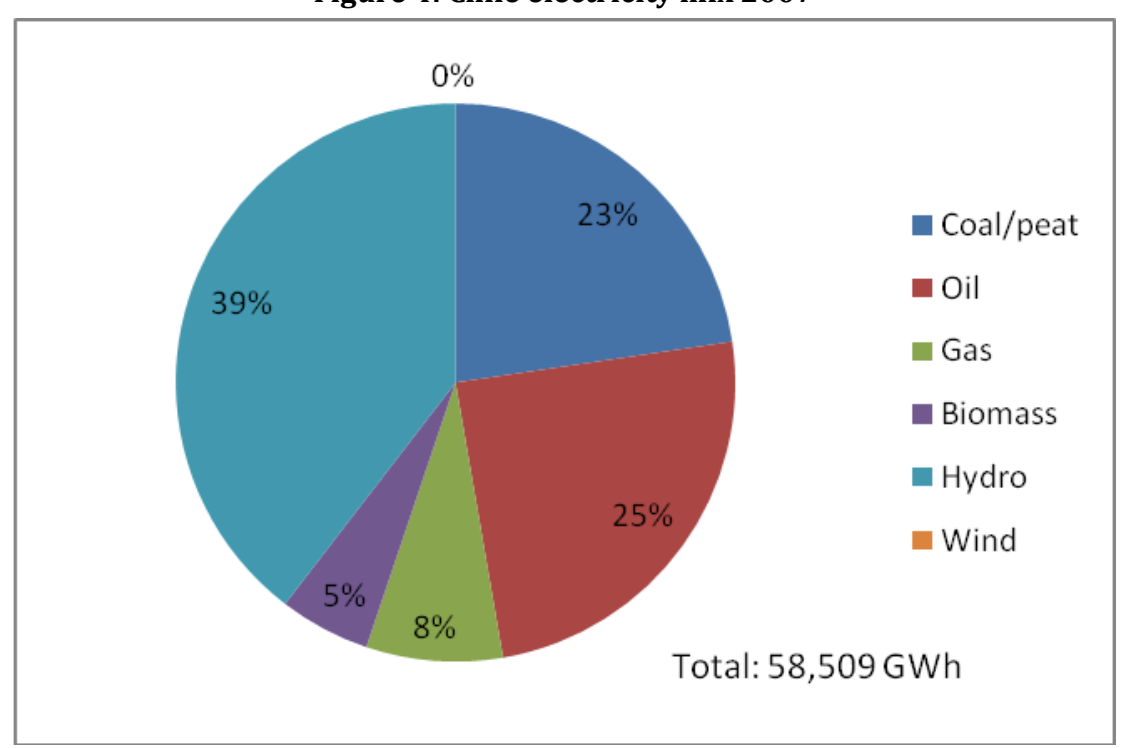

Source: IEA - OECD Electricity and Heat Generation

Chile's LNG programme is thus designed to reduce uncertainty in gas supply as well as to meet growing demand. The country's first LNG terminal was constructed in Quintero in central Chile. The first delivery to the terminal took place in July 2009 and the terminal is expected to be fully operational by the third quarter of 2010. The development of the terminal was phased in this way to accelerate the initial opening. The capacity of the terminal is $3.5 \mathrm{bcm}$ but could later be expanded to $7 \mathrm{bcm}$ (IEA, 2009b). This corresponds to between $1.5 \mathrm{mt}$ and $2.5 \mathrm{mt}$ per annum. The initial capacity of the terminal is equivalent to approximately 40\% of Chile's current demand for natural gas (BG Group, 2009).

The total capital cost of the terminal is $\$ 1.1$ billion. GNL Quintero S.A. was incorporated in 2007 as a public-private joint venture between ENAP, Endesa Chile, Metrogas S.A. of Santiago and BG Group. BG Group has a 40\% share and the other three partners have 20\% shares. ENAP is the state-owned oil and gas company; Endesa Chile is a private power generator and Metrogas is a private gas distributor. BG Group's partners have capacity rights in the terminal. They have entered into a 21-year contract with BG Group to off-take up to $2.3 \mathrm{bcm}$ from its global supply portfolio. Financing for the project is through a 15-year deal with 9 banks and BG Group affiliates. The loan is structured as non-recourse senior secured financing (BG Group, 2009). 
Figure 5: Electricity generation Chile

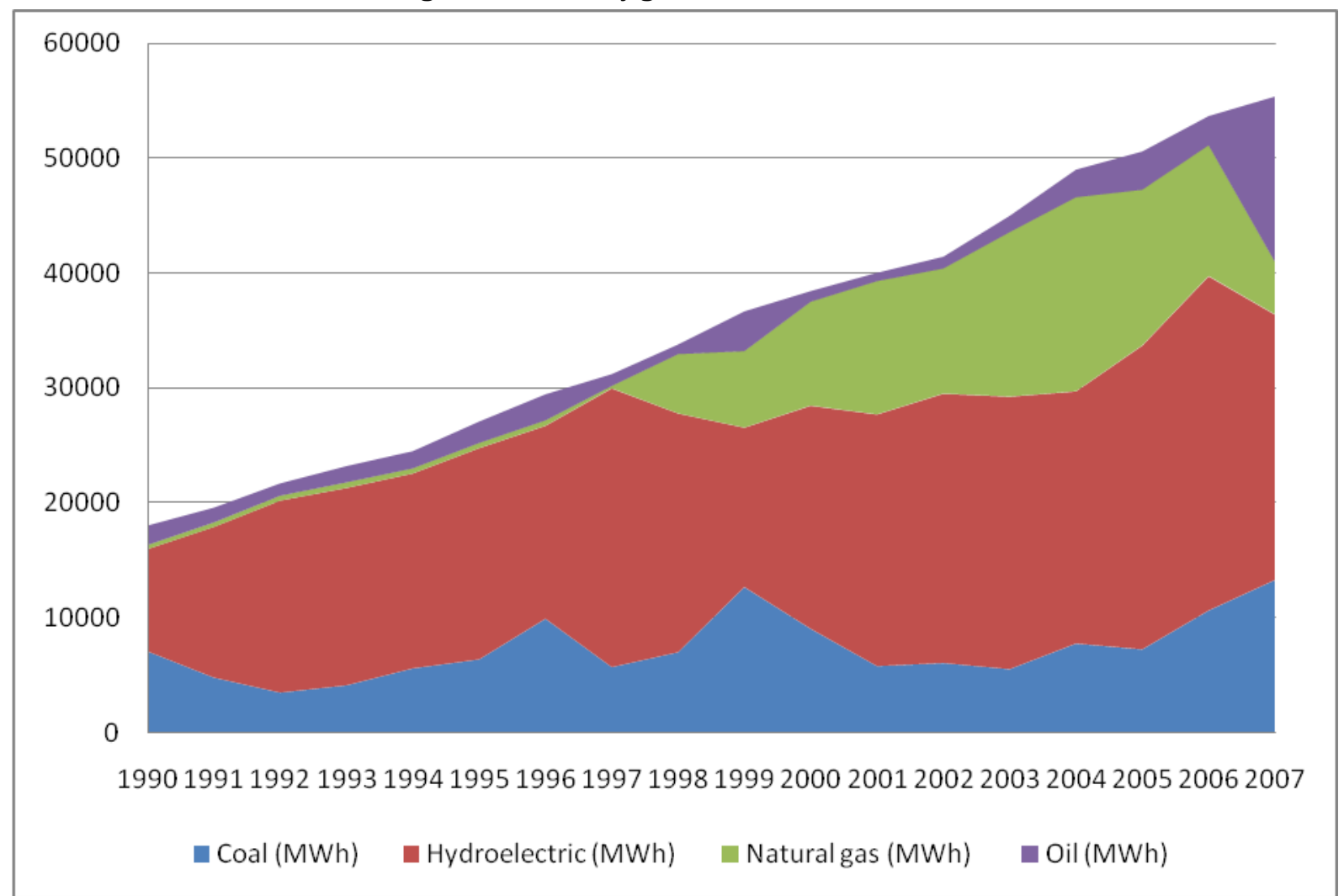

Source: World Development Indicators, World Bank

The second Chilean LNG terminal is located in the North at Mejillones, a region rich in minerals. This part of the country is even more dependent on gas and has few alternatives in the short-term. The project is a joint venture between multinational energy company GDF Suez and the state-owned copper mining company Codelco. Each partner owns $50 \%$ of the $1.8 \mathrm{bcm}$ capacity terminal. The total investment cost came to $\$ 500$ million. The terminal received its first shipment in February 2010 and started full commercial operations in May 2010. Capacity of the terminal is equivalent to approximately 1,100 MW of electricity generation. This is a substantial addition to the existing 3,596 MW capacity in the SING market of Northern Chile (GNL Mejillones, 2010).

Table 8: Summary of LNG terminal ownership Chile

\begin{tabular}{|c|c|c|c|c|}
\hline LNG Terminal & Organisation & Share & Ownership & $\begin{array}{l}\text { \% public } \\
\text { ownership }\end{array}$ \\
\hline \multirow{4}{*}{$\begin{array}{l}\text { Quintero } \\
\text { (Central) }\end{array}$} & BG Group & $40 \%$ & Publicly listed on LSE & $20 \%$ \\
\hline & ENAP & $20 \%$ & $\begin{array}{l}\text { State-owned oil and gas } \\
\text { company }\end{array}$ & \\
\hline & Endesa Chile & $20 \%$ & Private power generator & \\
\hline & Metrogas & $20 \%$ & Private gas distributor & \\
\hline \multirow{2}{*}{$\begin{array}{l}\text { Mejillones } \\
\text { (North) }\end{array}$} & GDF Suez & $50 \%$ & Multinational publicly & $50 \%$ \\
\hline & Codelco & $50 \%$ & $\begin{array}{l}\text { State-owned copper } \\
\text { company }\end{array}$ & \\
\hline
\end{tabular}


The strong mining customer base in the northern region is central to the viability of the project. LNG supply has been contracted by mining clients, including Codelco, BHP Billiton, Xstrata and Anglo America, as well as power generators in Chile's northern SING grid. Price agreements for LNG supply are tied to investment in the project rather than to market prices for the initial contract period from the beginning of 2010 to September 2012. After this initial phase, the clients will be able to avail of LNG supply at a lower price (Business News Americas, 2008; GNL Mejillones, 2010)

Table 9: LNG regasification terminals in South America

\begin{tabular}{|c|c|c|c|}
\hline Country & Terminal & Start up & Capacity (bcm) \\
\hline \multirow[t]{2}{*}{ Argentina } & $\begin{array}{l}\text { Bahía Bianca } \\
\text { GasPort (South) }\end{array}$ & May 2008 & 1.5 \\
\hline & $\begin{array}{l}\text { Pecém FSRU } \\
\text { (North) }\end{array}$ & January 2009 & 2 \\
\hline \multirow[t]{2}{*}{ Brazil } & $\begin{array}{l}\text { Guanabara Bay } \\
\text { (Rio de Janeiro) }\end{array}$ & March 2009 & 4.8 \\
\hline & $\begin{array}{l}\text { Tergas, Rio } \\
\text { Grande }\end{array}$ & 2013 & 2.2 \\
\hline \multirow[t]{2}{*}{ Chile } & $\begin{array}{l}\text { Quintero (Central) } \\
\text { (BG) }\end{array}$ & June 2009 & 3.4 \\
\hline & $\begin{array}{l}\text { Mejillones (North) } \\
\text { (GDF Suez) }\end{array}$ & 2010 & 1.8 \\
\hline
\end{tabular}

Source: IEA, 2009b

Chile is not alone in developing LNG capacity. Table 9 summarises recent LNG developments in South America. One of the main issues in developing LNG infrastructure is the cost of LNG relative to other sources of power generation, particularly coal. In the Chilean case, consumers may be willing to pay a premium for LNG as a substitute for imports from Argentina. It is not so clear, however, whether LNG can be competitive with coal for power generation (Barroso et al., 2008; IEA, 2009b).

\subsection{Electricity distribution in New Zealand}

In 1993, electricity supply authorities in New Zealand were corporatized. Ownership of most of the assets was transferred to trusts, cooperatives and a small number of privately owned companies. The prevalence of the trust model of ownership owes itself to the process of corporatizing rural Electric Power Boards (EPBs). The boards had been established in the early 1900s to install and manage network assets on behalf of consumers. When it came to transforming the boards into commercial companies, it was not clear who the owners should be. All consumers served by the boards at the time of restructuring were deemed to own the EPBs. As a result, a large number of trust-owned companies emerged (Bertram, 2006). 
Table 10: New Zealand at a glance

\begin{tabular}{ll}
\hline Total electricity generation & $43,774 \mathrm{GWh}$ \\
2008 & \\
Total gas demand 2008 & $159,936 \mathrm{TJ}$ \\
GDP per capita 2008 (PPP & $\$ 25,011$ \\
constant 2005) & $3.09 \%$ \\
GDP growth 2007 & $-1.1 \%$ \\
GDP growth 2008 & $\$ 0.164 / \mathrm{kWh}$ \\
$\begin{array}{l}\text { Electricity price for } \\
\text { households 2008 (including }\end{array}$ & \\
tax) & \\
Population 2008 & $4,268,900$ \\
\hline
\end{tabular}

Source: World Bank - World Development Indicators; IEA - Electricity information; EIA - Electricity prices for households

Since 1999, distribution companies have been required to specialize in distribution services and to be owned separately from competitive activities such as generation and retail (Bertram, 2006). Table 11 summarises the main types of ownership structure and gives some examples from the power sector.

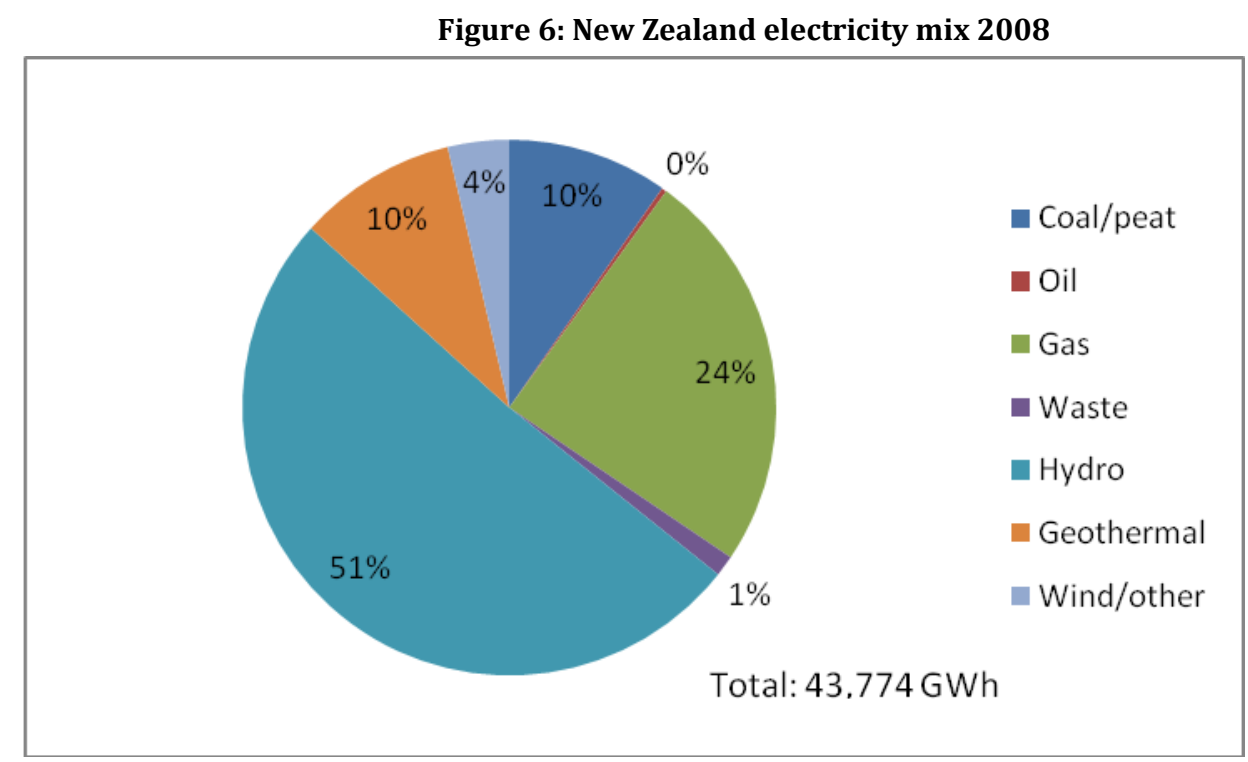

Source: IEA - OECD Electricity and Heat Generation 
Table 11: Electricity distribution companies in New Zealand

\begin{tabular}{|c|c|c|}
\hline Ownership type & Total & Examples \\
\hline Consumer trust & $\begin{array}{l}18 \text { (plus } 1 \text { with } \\
\text { minority ownership) }\end{array}$ & $\begin{array}{l}\text { Counties Power, Mainpower New } \\
\text { Zealand, The Lines Company, } \\
\text { Vector, Alpine Energy ( } 40 \% \\
\text { consumer trust; } 60 \% \text { local } \\
\text { authority) }\end{array}$ \\
\hline Local authority & 4 & $\begin{array}{l}\text { Aurora Energy, Orion New } \\
\text { Zealand }\end{array}$ \\
\hline Community trust & 2 & Eastland Network, WEL Networks \\
\hline Public & $\begin{array}{l}1 \text { (plus } 2 \text { with } \\
\text { minority ownership) }\end{array}$ & $\begin{array}{l}\text { Powerco, Horizon Energy } \\
\text { Distribution ( } 77 \% \text { consumer } \\
\text { trust, } 23 \% \text { public), Vector ( } 75.1 \% \\
\text { consumer trust, } 24.9 \% \text { public) }\end{array}$ \\
\hline Cooperative & 1 & Electricity Ashburton \\
\hline Other & 2 & $\begin{array}{l}\text { Nelson Electricity (equal ownership } \\
\text { by two consumer trusts; OtagoNet } \\
\text { Joint Venture ( } 2 \text { consumer trusts } \\
\text { and local authority) }\end{array}$ \\
\hline Total & 28 & \\
\hline
\end{tabular}

Source: Evans and Meade (2005)

In the early years of reform, New Zealand adopted a light-handed approach to regulating electricity distribution networks that relied solely on information disclosure. In 2001, the Commerce Commission was given the task of regulating both distribution and transmission networks. Following a thorough review of pricing practices in the industry by the Commission, the government decided to establish a dedicated industry regulator to oversee developments going forward. The Electricity Commission was created in 2003 and is now tasked with setting price and revenue caps, managing information disclosure, guiding new investment and coordinating the investment plans of different industry actors (Bertram 2006). Since 2008, the Commerce Commission has been responsible for setting and monitoring price path and quality thresholds for distribution and transmission. The main responsibility of the Commerce Commission over and above the Electricity Commission is to promote market competition and safeguard the long-term interests of consumers (Commerce Commission, 2007). Electricity distribution companies that are fully owned by consumer trusts, community trusts or cooperatives are exempt from price-quality regulation. They are still, however, subject to information disclosure rules set out by the Electricity Commission.

In the next three subsections, we describe the ownership model, board appointment process, capital and share structure for three markedly different electricity distribution companies in New Zealand.

\section{Consumer trust}

Vector is the largest electricity distribution company in New Zealand. It started out in 1994 as Mercury Energy Limited and was owned in full by the Auckland Energy Consumer Trust (AECT). In 1999 when it sold its electricity retail 
business, it changed its name to Vector Limited. In 2005, the company was floated on the New Zealand stock exchange in order to raise capital to buy gas company NGC Holdings. The AECT remains the majority shareholder with $75.1 \%$ ownership. The remaining shares are held by a variety of individual and institutional shareholders. Two of Vector's seven board members are AECT trustees. Trustee elections take place every three years. All elected trustees are electricity customers that live within the area of the Trust.

Vector has expanded its portfolio to include not only electricity distribution assets but also gas transmission pipelines, fibre optic networks, energy metering businesses and wind generation. Total electricity assets came to NZD 3.2 billion in 2009 (USD 2 billion) ${ }^{16}$. Vector's capital structure is divided almost equally between debt and equity: 48\% debt and 52\% equity (a total of NZD 5.5 billion or USD 3.5 billion) (Vector, 2009).

AECT is fully equity-financed (total of NZD 300 million - USD 190.7 million - in 2009). In 2009, AECT received a total of 99.5 million in dividends from Vector. This was distributed as a NZD 320 (USD 203) dividend to all 304,906 eligible beneficiaries, i.e. electricity customers living in the Trust's area (AECT).

\section{Local authority}

Orion New Zealand Limited was originally called Southpower when it was established in 1989 as a joint venture between Christchurch City Council, the Central Canterbury Electric Power Board, Riccarton Electricity and the Port Hills energy authority. Ownership was transferred to three local authorities in the supply area in 1992: Christchurch City Council, Selwyn District Council and Banks Peninsula District Council. Southpower sold its retail business in 1998 and the networks business was renamed Orion New Zealand Limited. In 1999, the company was delisted. Orion now has two shareholders: Christchurch City Council (89.275\%) and Selwyn District Council (10.725\%). The debt to equity ratio of the company for 2009 (total liabilities/shareholder equity) was 0.39 . The group's policy is to maintain a strong capital base in order to ensure confidence from the market, investors and creditors in the future of the business.

Total financial liabilities on the 2009 balance sheet for Orion were NZD 69.2 million (USD 44 million). Almost 70\% of these liabilities took the form of unsecured loans. Interest rates are floating based on bank bill rates plus a margin. The average rate as at the end of March 2009 was $3.83 \%$ and was $8.95 \%$ the previous year.

There are six non-executive directors in Orion. Five of these are appointed by the company's majority shareholder and one by the minority shareholder. At least one third of the directors must retire at the annual meeting but they can be reappointed (Orion, 2009).

\footnotetext{
16 All figures in USD in this section are calculated at the average 2009 exchange rate from the Federal Reserve Statistical Release, historical rates for New Zealand.
} 


\section{Community trust}

Eastland Network is an example of an electricity distribution company wholly owned by a community trust. The Eastland Energy Community Trust was created in May 1993. Since then, it has expanded its involvement beyond the energy sector. Assets include Eastland Port, Gisborne Airport, as well as land and property in the commercial sector. Electricity network assets totalled NZD 152 million in 2009 (USD 96.6 million) (ECT, 2009). The Trust can have no less than five and no more than seven trustees. All trustees are appointed by Gisborne District Council. Applications for appointment are advertised each year throughout the district. The main criteria for appointment are that the trustees are able to represent the interests of the community, as well as to ensure the successful operation of the Trust as a business (ECT, 1993).

Table 12: Outstanding loans Eastland Community Trust

\begin{tabular}{|c|c|c|c|}
\hline Bank loans & Currency & Nominal interest rate & $\begin{array}{l}\text { Face value } 2009 \\
\$ 000\end{array}$ \\
\hline Commonwealth bank & NZD & $3.94 \%$ & 30,000 \\
\hline $\begin{array}{l}\text { Commonwealth bank - } \\
\text { call }\end{array}$ & NZD & $3.3 \%$ & 1,250 \\
\hline Commonwealth bank & USD & $0.5 \%$ & 3,243 \\
\hline $\begin{array}{l}\text { Westpac Banking } \\
\text { Corporation }\end{array}$ & NZD & $3.89 \%$ & 36,000 \\
\hline $\begin{array}{l}\text { Westpac Banking } \\
\text { Corporation - call }\end{array}$ & NZD & $3.6 \%$ & 1,000 \\
\hline Total & & & 71,493 \\
\hline
\end{tabular}

Source: ECT 2009, p. 28

The purpose of the Trust is to protect the interests of its beneficiaries, i.e. electricity consumers in the Trust's area. In particular, the Trust ensures that adequate and affordable electricity supplies reach areas where installation and/or maintenance may not be commercially viable. Sustaining economic growth in the district by supporting business, community and other initiatives is also part of its broader mission.

The debt to equity ratio for the Eastland Community Trust as a whole for 2009 was 0.69 . Borrowings from banks constituted over $60 \%$ of total liabilities in 2009. Table 12 summarises the interest rates and amounts for each of the outstanding loans.

Even though the company is wholly owned by a community trust, only $81 \%$ of the network's customers are beneficiaries. This means that the company is not exempt from price/quality reviews and must submit information annually to the Electricity Commission (ECT, 2009). 


\subsection{Electricity and gas transmission in Northern Ireland}

\begin{tabular}{|c|c|}
\hline $\begin{array}{l}\text { Total electricity generation } \\
2008\end{array}$ & 390,321 GWh \\
\hline Total gas demand 2008 & $3,928,633 \mathrm{TJ}$ \\
\hline $\begin{array}{l}\text { GDP per capita } 2008 \text { (PPP } \\
\text { constant 2005) }\end{array}$ & $\$ 34,204$ \\
\hline GDP growth 2007 & $3.02 \%$ \\
\hline GDP growth 2008 & $0.71 \%$ \\
\hline $\begin{array}{l}\text { Electricity price for } \\
\text { households } 2008 \text { (including } \\
\text { tax) }\end{array}$ & $\$ 0.231 / \mathrm{kWh}$ \\
\hline Population 2008 & $61,414,062$ \\
\hline (Northern Ireland & $1,775,000)$ \\
\hline
\end{tabular}

Mutual Energy Northern Ireland owns the Moyle Interconnector between Northern Ireland and Scotland, the Scotland to Northern Ireland gas pipeline (SNIP) and the Belfast gas transmission line. The Moyle interconnector was the first asset acquired by the company in 2003 from previous owners Viridian, with a capital value of $£ 135$ million. The interconnector began full commercial operation in 2002. The company, then known as Northern Ireland Energy Holdings, purchased SNIP (valued at $£ 107$ million) in 2005 and the Belfast gas transmission line in 2008 ( $£ 109$ million). The company was renamed Mutual Energy Limited in November 2009.

Figure 7: UK electricity mix 2008

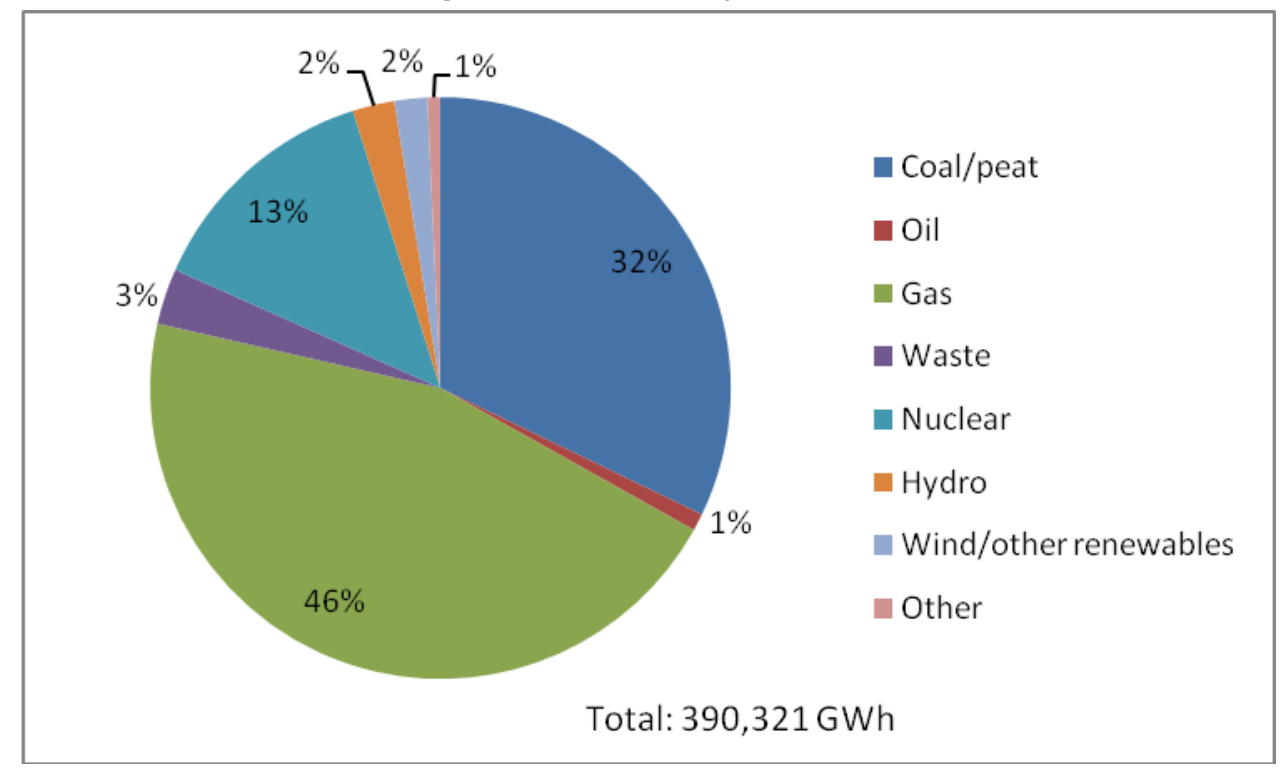


These three assets are central to the energy infrastructure in Northern Ireland and, in the case of the interconnector, to the electricity infrastructure of the whole island of Ireland. The interconnector has a total capacity of 500MW and provides an opportunity to increase competition in Ireland's Single Electricity Market. Figure 8 shows the power transfers between Northern Ireland and Scotland from June 2009 to May 2010, including the percentage of total Northern Ireland electricity consumption on the right axis. The SNIP is a 24-inch diameter pipeline that is $135 \mathrm{~km}$ long. The pipeline transports gas to Ballyumford Power Station which provides over $50 \%$ of Northern Ireland's power. The Belfast gas transmission pipeline is connected to the SNIP at Ballyumford and is a $26 \mathrm{~km}$ cross-country pipeline.

The mutual ownership model or the company limited by guarantee is essentially owned by members for the benefit of members. It is similar in purpose and structure to the consumer or community trust. In companies limited by guarantee, the members act as guarantors and there is usually no share capital and no shareholders. Financing for each of Mutual Energy's assets has been entirely debt-based. 
Table 14 summarises the details of the bonds for each of the three assets.

The board of directors of Mutual Energy is elected at the Annual General Meeting by company members. There are at least 30 members in the company. They are appointed by the board on the recommendation of a selections committee. The selections committee includes two non-executive directors, two members and two independent representatives nominated by the Northern Ireland Authority for Utility Regulation (NIAUR). Members do not receive remuneration and have no financial interest in the company. They are selected to ensure adequate representation from all stakeholder groups, but particularly from consumers.

Figure 8: Power transfers between Northern Ireland and Scotland

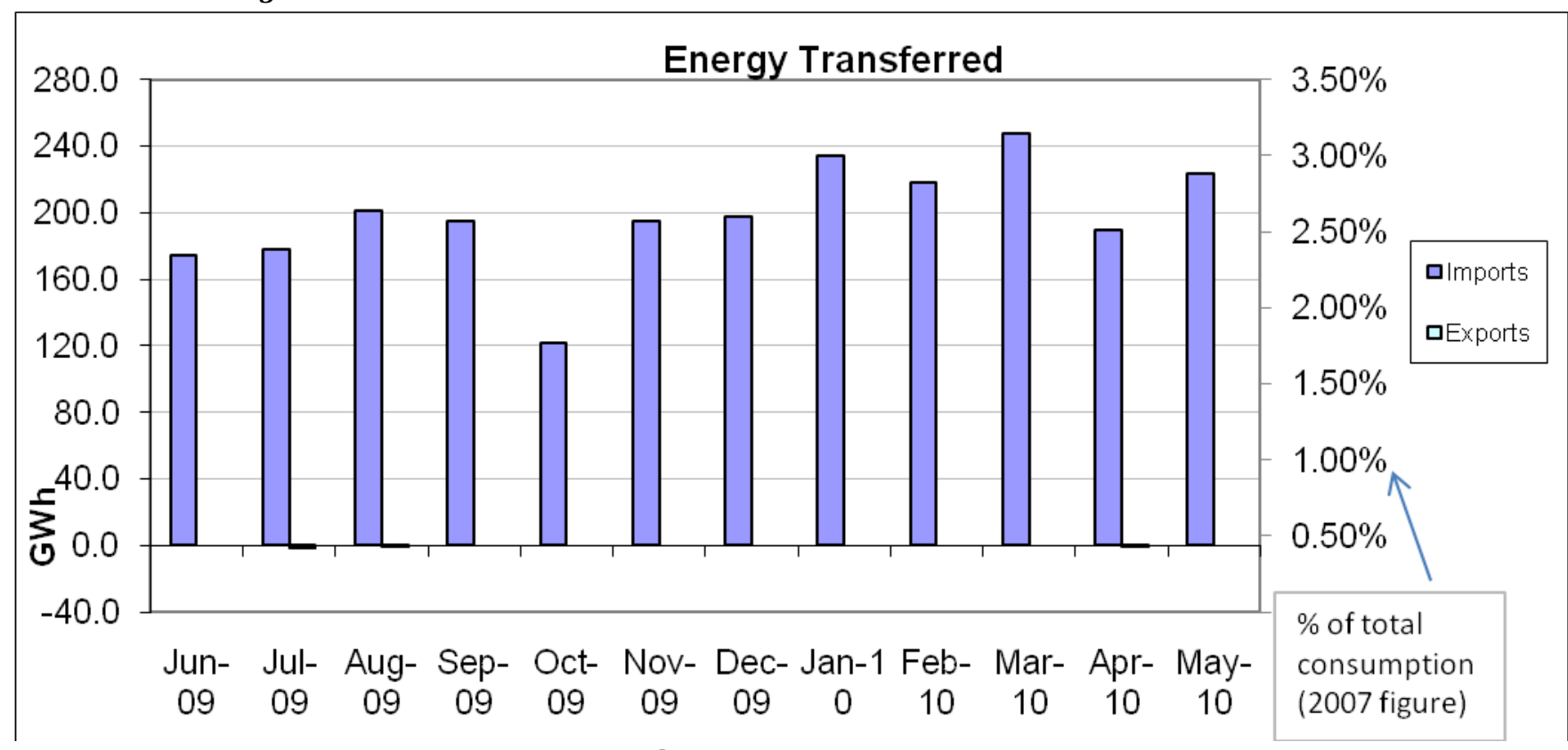

Source: Mutual Energy 2010 
Table 14: Mutual Energy's acquisitions

\begin{tabular}{|c|c|c|c|c|}
\hline Asset & Acquired & $\begin{array}{l}\text { Associated } \\
\text { bond issuance }\end{array}$ & Term & Real rate \\
\hline $\begin{array}{l}\text { Moyle } \\
\text { Interconnector }\end{array}$ & April 2003 & $£ 135 \mathrm{~m}$ & 30-year & $2.94 \%$ \\
\hline $\begin{array}{l}\text { Scotland to } \\
\text { Northern } \\
\text { Ireland } \\
\text { pipeline }\end{array}$ & March 2005 & $£ 107 \mathrm{~m}$ & 25-year & $2.46 \%$ \\
\hline $\begin{array}{l}\text { Belfast gas } \\
\text { transmission } \\
\text { pipeline }\end{array}$ & March 2008 & $£ 109 \mathrm{~m}$ & 40-year & $2.21 \%$ \\
\hline
\end{tabular}

Source: NIEH 2009

Mutual Energy is regulated through licence agreements with NIAUR. Revenue of both the gas and electricity businesses is regulated to match debt service costs and operating expenditure. In October each year, the actual revenue is reconciled with forecast revenue. If there is a shortfall, this can be collected through the system operator from electricity customers (NIEH, 2009).

The mutual model transfers equity risk to customers. On the one hand, this arrangement allows for reduced cost of capital. In the case of Northern Ireland, the model has been justified on the basis that the reduction in costs helps to tackle high energy prices. Performance to date shows that this has indeed been the case. For the Moyle interconnector, there has been a reported 25\% saving on the cost of capital over a non-mutual model. It has not been necessary to call on electricity customers for any shortfall in revenues. In fact, $£ 11.9 \mathrm{~m}$ had been set aside in accumulated reserves at the end of the 2008/9 financial year (NIEH, 2009).

On the other hand, one of the main problems identified with the mutual model is the lack of internal control. Equity-holders usually perform this role. In Mutual Energy, members of the company are appointed to fill this gap. Some argue, however, that the regulator essentially steps in and that the mutual model becomes nothing more than a "public delivery agency" (Helm and Tindall, 2009, p. 430). The share of debt in the capital structure of UK utilities has grown since privatisation. As we discussed in the case of the Moyle interconnector, this leads to a lower cost of capital because debt-holders have a higher incentive than equity-holders to limit risk. Access to debt markets, however, requires a healthy balance sheet. Financing new capital investments may become problematic particularly at times of economic uncertainty (Helm and Tindall, 2009). Some of this risk can, however, be limited as long as existing assets perform well and allow reserves to be accumulated, as in the case of the Moyle interconnector.

\subsection{ESCOs in Great Britain}

Energy Service Companies (ESCO) take many different forms both in Great Britain and internationally. There is no single definition of an ESCO. The term generally implies that an entity is engaged in activities that aim to improve 
energy efficiency, provide energy savings or reduce carbon emissions (London Energy Partnership, 2007). In Great Britain, there have been a number of ESCOs established as a means of developing Combined Heat and Power with District Heating schemes (CHP-DH). These schemes are community-based and have the potential to improve energy efficiency and to provide electricity and heat at lower cost to local consumers (Kelly and Pollitt, 2009).

London Energy Partnership (2007, p.4) illustrates how existing schemes in Great Britain vary according to the level of public and private sector involvement (which ranges from fully public, through mixed ownership to fully private). When the private sector enters, there is a degree of risk transfer depending on the degree of involvement.

Table 15 compares some CHP-DH schemes by assets, turnover and profit. In the next two subsections, we focus on the Aberdeen scheme as an example of an initiative driven by a local council and the Sheffield scheme which started out with public involvement but was transferred to the private sector.

Table 15: GB District Heating schemes

\begin{tabular}{|c|c|c|c|c|}
\hline Scheme & Cost to build CHP-DH & $\begin{array}{l}\text { Fixed assets (Present } \\
\text { Value 2006) }\end{array}$ & $\begin{array}{l}\text { Annual turnover } \\
\text { (3 year avg) }\end{array}$ & $\begin{array}{l}\text { Profit (loss) before } \\
\text { tax } \\
\text { (3 year avg) }\end{array}$ \\
\hline & $£$ million nominal & $£$ million & $£$ million & $£$ \\
\hline Barkantine & 6.0 & 3.4 & 1.1 & 96,000 \\
\hline Woking & 4.2 & 13.0 & 2.3 & $(41,000)$ \\
\hline Aberdeen & 6.5 & 5.4 & 0.23 & 14,522 \\
\hline Southampton & 8.0 & 6.2 & 2.8 & 33,509 \\
\hline Sheffield & Unavailable & 6.5 & 25.6 & $2,890,000$ \\
\hline
\end{tabular}

Source: Kelly and Pollitt (2009), p. 14

\begin{abstract}
Aberdeen
Aberdeen Heat and Power Ltd (AH\&P) was established in 2002 as a not-forprofit company owned in full by Aberdeen City Council. The company was set up to manage Combined Heat and Power (CHP) district heating schemes in the city. There are currently three completed schemes that provide 900 homes and 7 council-owned public buildings with space and water heating. The schemes are fuelled by mains gas. Plans to expand one of the schemes by installing a biomass CHP unit to supply heat to commercial buildings are under way (SSN 2009). The initial impetus for the schemes came from the need to address fuel poverty in Aberdeen's council-owned buildings and flats. CHP was found to be the most technically and economically efficient way of improving energy efficiency and
\end{abstract}


affordability. The three schemes currently operating are: Stockethill (210kWe); Hazlehead (300kWe); and Seaton (1MWe) (Kelly, 2008).

Table 16 describes the financing arrangements for the Aberdeen district heating schemes. The investment is supported through a combination of grants and a loan underwritten by the City Council. Financing for the bank loan is provided by the savings from newly installed energy efficiency measures. This type of financing arrangement ensures that the energy efficiency goals of the project remain central to its operation.

Table 16: Financing arrangements for Aberdeen Heat and Power

\begin{tabular}{lll}
\hline Source of financing & $\begin{array}{l}\text { Amount (share of } \\
\text { total investment) } \\
£ 2.68 \text { million }\end{array}$ & Details \\
$\begin{array}{l}\text { Energy Saving Trust, } \\
\text { Community Energy }\end{array}$ & $\begin{array}{l}\text { Grant to stimulate the } \\
\text { Programme }\end{array}$ & $\begin{array}{l}\text { development of CHP } \\
\text { community heating networks } \\
(2000-2005)\end{array}$ \\
Bank loan & $£ 3.51$ million & $\begin{array}{l}\text { Underwritten by Aberdeen } \\
\text { City Council; financed through } \\
\text { savings from new energy } \\
\text { efficiency measures } \\
\text { Small number of grants for } \\
\text { energy efficiency investments } \\
\text { associated with the CHP } \\
\text { schemes }\end{array}$ \\
Energy Efficiency & $£ 273,000(4 \%)$ & \\
Commitment & & \\
& &
\end{tabular}

AH\&P is owned by Aberdeen City Council but was established as an independent, not-for-profit company limited by guarantee. This was an innovative way for the Council to overcome its own financial constraints which would have delayed the development of a community district heating network considerably. The company has a contract with the City Council to provide heat to council buildings (King, 2007). AH\&P has a board of unpaid directors including two tenant representatives, two elected members and five independent directors. A number of specialist advisors provide project design and management expertise. The company has a contract, for example, with a CHP consultant (ACC, 2004). Any surplus income generated from the schemes provides part of the capital for the next phases of development of Aberdeen's district heating network. Current expansion plans aim to expand capacity to $3 \mathrm{MWe}$ of electricity and $4.2 \mathrm{MW}$ heat, with an estimated total cost of $£ 2.9$ million (AH\&P, 2010).

\section{Sheffield}

The dominant model for ESCO development in the UK has centred on direct municipal involvement. Sheffield Heat and Power (SH\&P) started out this way in 1988 but is now an example of an ESCO on the private sector end of the spectrum. In 2001, Onyx (now Veolia Environmental Services) was awarded a 35-year Integrated Waste Management contract for Sheffield City Council. The company paid the council $£ 47$ million at the time (Onyx, 2001). Included in the 
contract is the management of a waste-to-energy plant (an energy recovery facility) as well as the district heating network and the refuse collection and recycling service. The waste-to-energy plant was rebuilt in 2006 as part of the agreement with the Council. It now generates up to $21 \mathrm{MW}$ of electricity and $60 \mathrm{MW}$ of heat, making it the largest CHP plant to serve a district heating scheme in the UK (Kelly, 2008). Over 140 commercial and public as well as 2,800 residential buildings are connected to the district heating network (Veolia, 2008).

When Onyx was awarded the waste management contract for Sheffield in 2001, Onyx Sheffield was predominantly debt-financed as can be seen from Table 17. The split between debt and equity has, however, become more equal since then.

Veolia Environmental Services is the largest private waste disposal company in the UK with over 12,500 employees and revenues above $£ 1.3$ billion. Veolia has a contract with the Sheffield City Council to operate and maintain the district heating scheme. The contract covers the entire cycle from waste collection to energy delivery. Veolia enters into contracts directly with private customers for heat supply. Council-owned housing and public buildings constitute a large part of the customer based. Any electricity that is generated is sold to the National Grid under an agreement with a guaranteed long-term supply price (Kelly, 2008).

Table 17: Onyx Sheffield's capital structure

\begin{tabular}{lll}
\hline Year & Total debt & Total shareholders' \\
& & equity \\
2001 & $£ 3,820,000$ & $£ 230,000$ \\
2008 & $£ 2,827,000$ & $£ 2,421,000$ \\
\hline
\end{tabular}

Source: Onyx Sheffield, 2001; Veolia ES Sheffield, 2008

The parent company of Veolia Environmental Services is Veolia Environnement. Covering a wide spectrum of energy and environmental services, Veolia Environnement operates in 72 countries with 2008 revenues of more than €36 billion. One of Veolia's main strengths is its ability to approach waste disposal in an integrated way. They support an integrated approach to Private Finance Initiatives as a means of building new infrastructure for waste management (Veolia, 2008). Sheffield district heating network is a good example of this longterm integrated approach.

\subsection{Drivers of ownership models}

The ownership models we have explored have arisen for a variety of reasons, often dependent on country or regional context. Looking at our six case studies, we can identify three categories of drivers for public or consumer involvement. The first is demand-related. Consumers in Denmark, Finland and Chile played a central role in pushing for new ownership arrangements in wind, nuclear and LNG. In Denmark, the push from communities for wind power development was later supported and sustained by policy changes. In Finland and Chile, industrial consumer needs as well as uncertainty, particularly in the Chilean case due to 
difficulties with Argentinian supply, led to the creation of new partnerships and innovative financing arrangements.

The second category is social objectives. Meeting the needs of vulnerable consumers has been at the heart of many ESCO schemes in Great Britain. Tackling fuel poverty has required involvement from local authorities to start with. Some of the schemes have developed to the point where additional services have been integrated, making it more attractive for private sector entry. In Northern Ireland, the driving force behind the creation of a new ownership model for transmission assets came from the desire to protect all consumers from traditionally high energy prices. Consumer involvement was seen as the best way of achieving this. The regulatory framework in New Zealand also encourages direct consumer ownership by exempting wholly owned trusts from price-quality regulation.

The high levels of consumer involvement as well as direct public involvement through local authorities in New Zealand are also a legacy of the transition to corporatisation. This is also true to a certain in extent in the case of Finland. The large share of nuclear in power system sustains new types of financing for new investment but is a legacy of past arrangements, particularly the establishment of TVO in the 1960s by Finnish industrial and power companies.

\section{Conclusions}

Public ownership remains potentially significant in and for the power sector. The above case studies provide a variety of examples of the nature of modern public ownership. They show that public involvement can co-exist with generally liberalised electricity markets, including at the retail market level. They also demonstrate that public 'ownership' can take a significant number of forms including: mutual ownership (e.g. Mutual Energy Holdings in Northern Ireland), consumer trusts (e.g. some EPBs in New Zealand), state ownership (e.g. ENAP in Chile, Fortum in Finland) and municipal ownership (e.g. some EPBs in New Zealand and some ESCOs in Great Britain). They further illustrate the mechanisms by which accountability operates via the selection processes for boards of directors.

There are good reasons to think that the case for mixed public-private ownership models in energy is improving. However it is important to point out that the theoretical case for significant private ownership within most national energy systems remains strong. Many countries have in fact yet to introduce any significant private involvement in their electricity and gas sectors. Furthermore, while allowing multiple ownership forms to co-exist sounds attractive, it may impose significant whole system costs. For instance, the move towards privatising almost all publicly owned energy assets in the UK allowed the government to close the Department of Energy between 1992 and 2008 (when it reopened as a Department of Energy and Climate Change) largely because 
energy policy for that period could be summarised in one phrase: 'leave it to the market'. ${ }^{17}$

Several key questions are suggested by the paper:

The ability of public entities to reduce the amount of equity in their businesses and to borrow at very low interest rates remains a clear motivation for public ownership. This has always been a key driver (see Kwoka, 1996). This raises the issue of whether the benefits of public ownership are related to a genuine reduction in risk relative to private ownership (say due to reduced risk of appropriation). They could simply be due to a potentially inefficient (and unclear) shifting of risks on to taxpayers, away from private investors who would be better able to manage them. Equally, the lower borrowing cost associated with special purpose vehicles for electricity transmission assets (e.g. in Northern Ireland) or low risk electricity distribution utilities (e.g. in New Zealand) may be more to do with the market's preference for unbundling low risk assets from higher risk ones (in other jurisdictions or in other parts of the supply chain) rather than public ownership and governance arrangements per se. Simply put, are the nominal financing cost reductions observed under public ownership actually genuine improvements in social welfare requiring public ownership?

Innovative forms of new public ownership exist in institutional environments which are open to institutional innovation and willing to experiment with ownership and governance arrangements. If competition in ownership forms and innovation in terms of ownership and governance structures is desirable, what prevents different ownership forms from emerging?

New forms of public ownership have been sharpened by competition with the private sector. Indeed one could argue that the very success of privatisation forced a benchmarking of public enterprises against their private peers. There does not appear to be any justification for a return to the large wholly government owned monopoly SOEs of the past. In all the jurisdictions represented by our case studies, private ownership exists and is clearly an institutional option for underperforming publicly owned firms. If public ownership is to be encouraged, this needs to be within a context where the benefits of competition from the private sector are maintained. Thus, how can we maintain benefits of both private and public involvement?

Finally, it is important to stress that the current challenges facing the power sector are not uncontroversial, in the sense that they may be self-imposed, illusory and subject to other forms of mitigation rather than public ownership of energy assets. Thus the incompleteness of energy market reform is not necessarily desirable in many jurisdictions. Climate change policy could be significantly simplified and more effective if it involved the imposition of a high, stable and credible carbon price. Energy security concerns are best handled by

17 The costs of having different ownership forms do not have to be significant, if publicly owned firms are operated as if they were privately owned firms. However this would obviate the rationale for public ownership. 
allowing private investors to assess risks in a world of increasingly globally integrated oil and gas markets. Consumer engagement can be organised via effective regulation or public advocacy. Finally, the impact of the financial crisis on investment in energy may be best mitigated by redoubling efforts to create well-functioning market and regulatory institutions. Thus in the end, we should ask, to what extent is improving case for public involvement in energy driven by ill-defined policy objectives and incomplete markets?

In closing, we acknowledge that our analysis poses more questions than it is capable of resolving. Revisiting our case studies in the near future would allow us to evaluate how successful they have been in achieving their objectives. 


\section{References}

ACC (2004). Combined Heat and Power developments linked to multi-storey flats at Seaton and Hazlehead. Aberdeen City Council, March 30.

AECT. "About your AECT dividend". Auckland Energy Consumer Trust, accessed 23 June 2010, available at: http://www.aect.co.nz/dividend/about-thedividend

Barroso, L.A., H. Rudnick, S. Mocarquer, R. Kelman, B. Bezerra (2008)."LNG in South America: the markets, the prices and the security of supply," Power and Energy Society General Meeting - Conversion and Delivery of Electrical Energy in the 21st Century, 2008 IEEE, Pittsburgh, 20-24 July 2008.

Bertram, G. (2006). Restructuring the New Zealand Electricity Sector 1984-2005. Electricity market

reform: An international perspective. F. P. Sioshanis and W. Pfaffenberger. Oxford, UK, Elsevier Ltd.: 203-234.BG Group (2009). Annual report and accounts 2009. BG Group plc, Reading, Berkshire.

Birchall (2002). "Mutual, non-profit or public interest company? An evaluation of options for the ownership and control of water utilities." Annals of Public \& Cooperative Economics 73(2): 181.

Bolinger, M. (2001). Community wind power ownership schemes in Europe and their relevance to the United States. Berkeley, California, Lawrence Berkeley National Laboratory. Business News Americas (2008). "GDF Suez official: Mejillones LNG price tied to project cost". Business News Americas, October 14. Downloaded 15 June 2010, Factiva.

Commerce Commission (2007). "Memorandum of Understanding between the Electricity Commission and the Commerce Commission", August 16 2007, available at: http://www.comcom.govt.nz/electricity-resources/

Danish Energy Agency. Danish Key Figures 2008, accessed 22 June 2010. Available at: http://www.ens.dk/enUS/Info/FactsAndFigures/KeyFigures/Sider/DanishKeyFigures.aspx

Domah, P. and Pollitt, M.G. (2001). 'Restructuring and privatisation of electricity distribution and supply businesses in England and Wales: a social costbenefit analysis', Fiscal Studies, 22(1): 107-146.

Dong Energy (2009). Annual report 2009, Fredericia, Denmark.

Dorigoni, S. and S. Portatadino (2008). "LNG development across Europe: Infrastructural and regulatory analysis." Energy Policy 36(9): 3366-3373

ECT (2009). Annual report 2009, Eastland Community Trust, Gisborne, New Zealand. 
ECT (1993). Deed creating the Eastland Energy Community Trust. Eastland Energy Community Trust, Gisborne, New Zealand.

Evans, L. T. and R. B. Meade (2005). Alternating currents or counter-revolution?: Contemporary electricity reform in New Zealand. Wellington, Victoria University Press.

EWEA (undated). Wind energy development in the EU 1998 to 2009. European Wind Energy Association. Available at: http://www.ewea.org/index.php?id=1486 Accessed June 2010.

Fouquet, R. and Pearson, P.J.G. (2006). 'Seven Centuries of Energy Services: The Price and Use of 177. Light in the United Kingdom (1300-2000)', Energy Journal, 27 (1), pp.139-

Gilbert, R. J. and D. M. Newbery (1994). "The Dynamic Efficiency of Regulatory Constitutions." The RAND Journal of Economics 25(4): 538-554.

GNL Mejillones (2010). "LNG as a cornerstone for reliable power supply in the north of Chile". Platts $9^{\text {th }}$ Liquefied Natural Gas Conference, February 25, Houston.

Hart, O. and J.Moore (1990). "Property Rights and the Nature of the Firm," Journal of Political Economy, 98(6): 1119-58.

Hart, O., A.Shleifer and R.W.Vishny (1997), 'The proper scope of government: Theory and application to prisons', Quarterly Journal of Economics, 112(4): 1127-58.

Helm, D. and T. Tindall (2009). "The evolution of infrastructure and utility ownership and its implications." Oxford Review of Economic Policy 25(3): 411-434.

IEA (2009a). Energy prices and taxes: Fourth quarter 2009. Paris, International Energy Agency.

IEA (2009b). Natural Gas Market Review 2009. Paris, International Energy Agency.

IEA (2007). Energy policies of IEA countries: Finland 2007 review. Paris, International Energy Agency.

Jamasb, T., Mota, R., Newbery, D. and Pollitt, M. (2005). 'Electricity sector reform in developing countries: a survey of empirical evidence on determinants and performance', World Bank Policy Research Working Paper Series, No.3549. World Bank. 
Kanter (2009). "In Finland, nuclear renaissance runs into trouble". May 28, New York Times, available at: http://www.nytimes.com/2009/05/29/business/energyenvironment/29nuke.html? $\mathrm{r}=1$

Kelly, S. (2008). Economic viability of combined heat and power district heating networks in the United Kingdom: A comparative approach. Department of Engineering. University of Cambridge. MPhil in Engineering for Sustainable Development.

Kelly, S. and M. G. Pollitt (2009). Making combined heat and power district heating networks in the United Kingdom economically viable: A comparative approach. Cambridge, EPRG Working Paper 0925/ Cambridge Working Paper in Economics 0945.

King, M. (2007) “Energy Services Companies”. LEP Forum event, March 22, London.

Kwoka, J.E. (1996). Power Structure: ownership, integration and competition in the US, Norwell, MA: Kluwer.

Laffont, J.-J. and J. Tirole (1993). A theory of incentives in procurement and regulation. London, MIT Press.

Larsen, J. H. M., H. C. Sorensen, et al. (2005). Experiences from Middelgrunden 40 MW offshore wind farm. Offshore Wind. Copenhagen.

Lipp, J. (2007). "Lessons for effective renewable electricity policy from Denmark, Germany and the United Kingdom." Energy Policy 35(11): 5481-5495.

Littlechild, S.C. (2006). 'Foreword: The Market versus Regulation', In Sioshansi, F.P. and Pfaffenberger, W. (eds.), Electricity Market Reform: An International Perspective, Oxford: Elsevier.

London Energy Partnership (2007). Making ESCOs work: Guidance and advice. London, London Energy Partnership.

Meyer, N. I. (2007). "Learning from wind energy policy in the EU: lessons from Denmark, Sweden and Spain." European Environment 17(5): 347-362.

Middelgrunden Wind Cooperative. "Bylaws of the Middelgrunden Wind Turbine Cooperative", accessed 3 June 2010, available at: http://www.middelgrunden.dk/middelgrunden/?q=en/node/72

Millward, R. (2010). NEWPEN - An Agenda for a New Public Enterprise - Keynote address, Milan, $10^{\text {th }}$ June. 
Mills, R. (2008). The Myth of the Oil Crisis, Westport, CT: Praeger.

Mutual Energy (2010). "Physical flows data". Accessed 24 June 2010, available at: http://www.mutualenergy.com/The Moyle Interconnector/Interconnector Physical Flows.p $\underline{\mathrm{hp}}$

Newbery, D.M. and Pollitt, M.G. (1997), 'The restructuring and privatisation of Britain's CEGB: was it worth it?', Journal of Industrial Economics, 45(3): 269-303.

NIEH (2009). Annual report 2009, Northern Ireland Energy Holdings, Belfast.

Noel, P. (2009). A Market Between Us: Reducing the Political Cost of Europe's Dependence on Russian Gas, Electricity Policy Research Group Working Paper Series, No.0916.

Ofgem (2010). Project Discovery Options for delivering secure and sustainable energy supplies, Ref.16/10, London: Ofgem.

Onyx (2001). Report and financial statement 2001. Onyx Environmental Group plc, London.

Onyx Sheffield (2001). Annual report 2001, Onyx Sheffield Limited, downloaded from Companies House UK.

Orion (2009). Annual report 2009, Orion Group, Christchurch, New Zealand.

Pollitt, M. G. (2010). UK renewable energy policy since privatisation. Cambridge, EPRG Working Paper 1002/ Cambridge Working Paper in Economics 1007.

Pollitt, M.G. (2009), Electricity Liberalisation in the European Union: A Progress Report', Mercato

Concorrenza Regole 3/2009, pp.497-523. [ In Italian]; English Version: EPRG Working Paper No.0929.

Pollitt, M. (2008a). 'Liberalisation and regulation in electricity systems: how can we get the balance right?', In Sioshansi, F.P. (ed.): Competitive electricity markets: design, implementation and performance. Oxford: Elsevier.

Pollitt, M. (2008b). 'Electricity reform in Argentina: lessons for developing countries', Energy Economics, 30(4): 1536-1567.

Pollitt, M. (2004). 'Electricity reform in Chile: lessons for developing countries', Journal of Network Industries, 5(3-4): 221-262. 
Pollitt, M.G. (1995). Ownership and Performance in Electric Utilities. Oxford, Oxford University Press.

Shleifer, A. and Vishny, R. (1994). Politicians and Firms, Quarterly Journal of Economics, 109 (4): 995-

1025.

Sorensen, H. C., L. K. Hansen, et al. (2002). Middelgrunden 40 MW offshore wind farm Denmark: Lessons learned. After Johannesberg, local energy and climate policy: From experience gained towards new steps - wind energy and involvement of local partners. Munich, Germany.

SSN (2009). “Aberdeen City Council”, Sustainable Scotland Network. Accessed 29 June 2010, available at: http://www.sustainablescotland.net/page.asp?pg=48

TVO (2009). Annual review 2009. Teollisuuden Voima Oyj, Finland.

Vector (2009). Shareholder review 2009. Vector Limited, Auckland, New Zealand.

Veolia (2008). Annual Review 2008: Sustainable growth is in our hands. Veolia Environmental Services, London.

Veolia Sheffield (2008). Report and financial statements 2008, Veolia ES Sheffield Limited, downloaded from Companies House UK.

The Wind Power. "Wind turbines and windfarms database", accessed 29 June 2010, available at:

http://www.thewindpower.net/statistics countries.php

Victor, D.G. and T.C.Heller (eds.) (2007). The Political Economy of Power Sector Reform: The

Experiences of Five Major Developing Countries, Cambridge: Cambridge University Press. 